\title{
Application of Acoustic and Optic Methods for Estimating Suspended-Solids Concentrations in the St. Lucie River Estuary, Florida
}

By Eduardo Patino and Michael J. Byrne

Prepared in cooperation with the

SOUTH FLORIDA WATER MANAGEMENT DISTRICT

Scientific Investigations Report 2004-5028

U.S. Department of the Interior

U.S. Geological Survey 


\title{
U.S. Department of the Interior \\ Gale A. Norton, Secretary \\ U.S. Geological Survey \\ Charles G. Groat, Director
}

\section{U.S. Geological Survey, Reston, Virginia: 2004}

\author{
For sale by U.S. Geological Survey, Information Services \\ Box 25286, Denver Federal Center \\ Denver, CO 80225 \\ For more information about the USGS and its products: \\ Telephone: 1-888-ASK-USGS \\ World Wide Web: http://www.usgs.gov/
}

\footnotetext{
Any use of trade, product, or firm names in this publication is for descriptive purposes only and does not imply endorsement by the U.S. Government.

Although this report is in the public domain, permission must be secured from the individual copyright owners to reproduce any copyrighted materials contained within this report.

Suggested citation:

Patino, Eduardo, and Byrne, M.J., 2004, Application of acoustic and optic methods for estimating suspendedsolids concentrations in the St. Lucie River Estuary, Florida: U.S. Geological Survey Scientific Investigations Report 2004-5028, 23 p.
} 


\section{Contents}

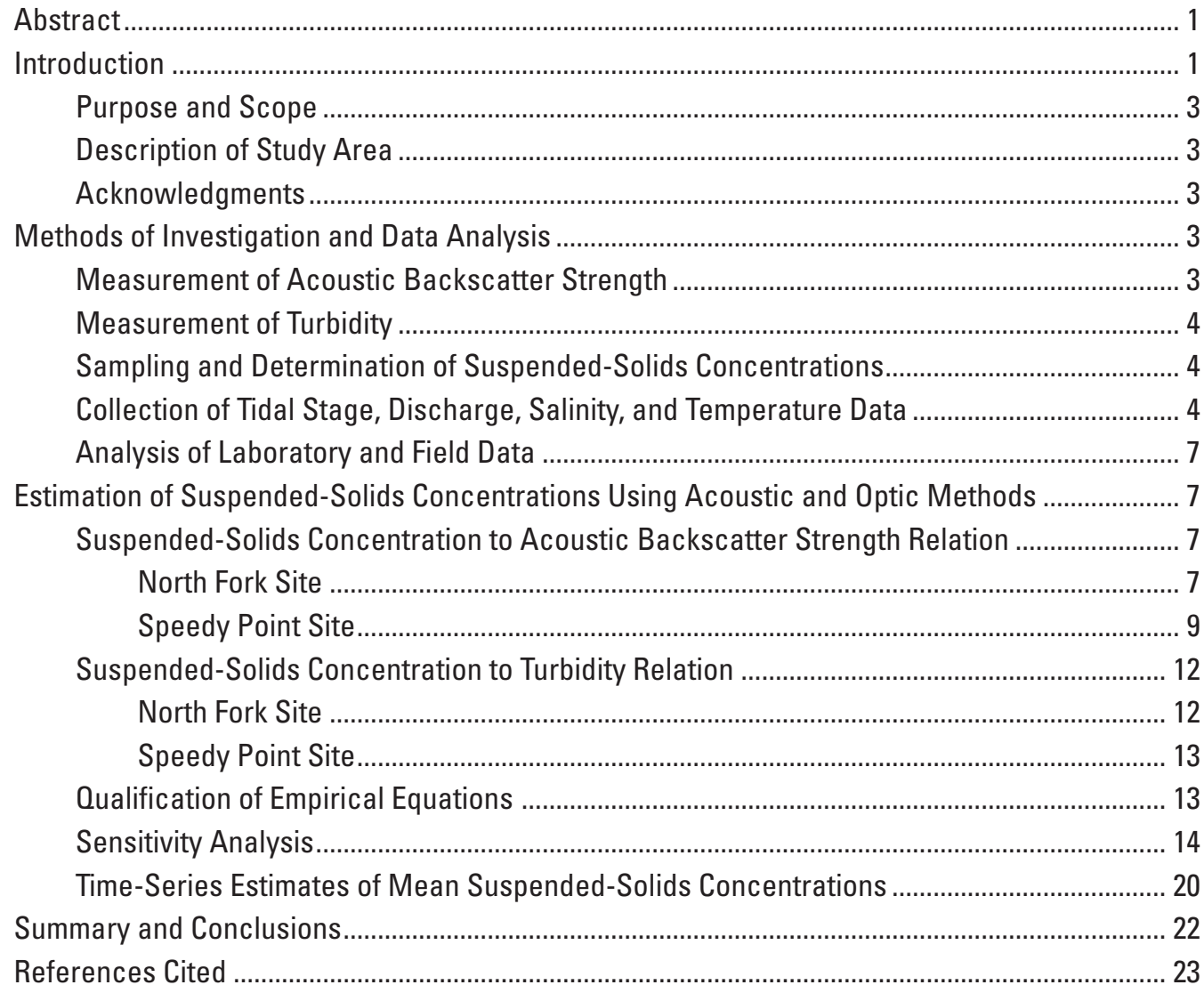

\section{FIGURES}

1. Map showing location of monitoring sites in the St. Lucie River Estuary study area...... 2

2. Diagram showing instrument setup for the monitoring sites in the St. Lucie River Estuary

3-6. Photographs showing:

3. Extent of biofouling of turbidity and salinity probes between field maintenance visits at a monitoring site in the St. Lucie River Estuary ......................................... 5

4. Sampling equipment used for suspended-solids measurements ......................... 5

5. Collection of an integrated water sample for suspended-solids concentration analysis.

6. A monitoring site (Steele Point) in the St. Lucie River Estuary ............................... 6

7-10. Graphs showing:

7. Measured to estimated suspended-solids concentration relation at the North Fork site using acoustic backscatter strength data

8. Measured to estimated suspended-solids concentration relation at the Speedy Point site using acoustic backscatter strength data .............................. 12

9. Suspended-solids concentration to turbidity relation at the North Fork site ....... 13

10. Suspended-solids concentration to turbidity relation at the Speedy Point site .. 14 
11-14. Graphs showing distribution of parameter data and residuals used in the suspended-solids concentration to:

11. Acoustic backscatter strength regression analysis at the North Fork site 15

12. Acoustic backscatter strength regression analysis at the Speedy Point site .... 16

13. Turbidity regression analysis at the North Fork site ............................................. 17

14. Turbidity regression analysis at the Speedy Point site......................................... 18

15-20. Graphs showing:

15. Acoustic backscatter strength to suspended-solids concentration relation at the North Fork and Speedy Point sites

16. Salinity to suspended-solids concentration relation at the North Fork and Speedy Point sites

17. Temperature to suspended-solids concentration relation at the North Fork and Speedy Point sites.

18. Effect of temperature on acoustic backscatter strength ..................................... 20

19. Local point to mean cross-sectional relation for suspended-solids concentration at the North Fork site....................................................................... 21

20. Local point to mean cross-sectional relation for suspended-solids

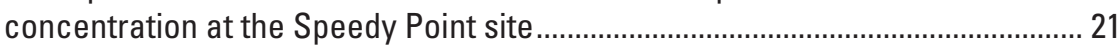

21. Time-series plot showing discharge and mean cross-sectional suspended-solids concentrations at the North Fork site

\section{TABLES}

1. Point sample data from the North Fork site used for regression analyses....................... 8

2. Point sample data from the Speedy Point site used for regression analyses................. 10

3. Suspended-solids concentrations for the North Fork and Speedy Point sites used to develop local to mean cross-sectional relations. 


\title{
Conversion Factors, Acronyms, Abbreviations, and Datums
}

\begin{tabular}{lcl}
\hline Multiply & By & To obtain \\
\hline inch (in.) & 25.4 & millimeter \\
foot (ft) & 0.3048 & meter \\
mile (mi) & 1.609 & kilometer \\
square mile $\left(\mathrm{mi}^{2}\right)$ & 2.59 & square kilometer \\
\hline
\end{tabular}

\section{Acronyms}

$\begin{array}{rll}\text { ABS } & \text { Acoustic backscatter strength } \\ \text { ADCP } & \text { Acoustic Doppler current profiler } \\ \text { ADVM } & \text { Acoustic Doppler velocity meter } \\ \text { EDI } & \text { Equal discharge increment } \\ \text { GOES } & \text { Geostationary Operational Environmental Satellite } \\ \text { NWIS } & \text { National Water Information System } \\ \text { PVC } & \text { Polyvinyl chlorinated } \\ \text { SJRWMD } & \text { St. Johns River Water Management District } \\ \text { SFWMD } & \text { South Florida Water Management District } \\ \text { SWIM } & \text { Surface-Water Improvement and Management } \\ \text { USGS } & \text { U.S. Geological Survey }\end{array}$

\section{Water-Quality Abbreviations}

\author{
$\mathrm{mg} / \mathrm{L} \quad$ milligrams per liter \\ NTU nephelometric turbidity units \\ ppt parts per thousand
}

Temperature in degrees Fahrenheit $\left({ }^{\circ} \mathrm{F}\right)$ may be converted to degrees Celsius $\left({ }^{\circ} \mathrm{C}\right)$ as follows:

$$
{ }^{\circ} \mathrm{C}=\left({ }^{\circ} \mathrm{F}-32\right) / 1.8
$$

Vertical coordinate information is referenced to the National Geodetic Vertical Datum of 1929 (NGVD 1929); horizontal coordinate information is referenced to the North American Datum of 1983 (NAD83). 


\title{
Application of Acoustic and Optic Methods for Estimating Suspended-Solids Concentrations in the St. Lucie River Estuary, Florida
}

\author{
By Eduardo Patino and Michael J. Byrne
}

\section{Abstract}

Acoustic and optic methods were applied to estimate suspended-solids concentrations in the St. Lucie River Estuary, southeastern Florida. Acoustic Doppler velocity meters were installed at the North Fork, Speedy Point, and Steele Point sites within the estuary. These sites provide varying flow, salinity, water-quality, and channel cross-sectional characteristics. The monitoring site at Steele Point was not used in the analyses because repeated instrument relocations (due to bridge construction) prevented a sufficient number of samples from being collected at the various locations. Acoustic and optic instruments were installed to collect water velocity, acoustic backscatter strength (ABS), and turbidity data that were used to assess the feasibility of estimating suspendedsolids concentrations in the estuary. Other data collected at the monitoring sites include tidal stage, salinity, temperature, and periodic discharge measurements.

Regression analyses were used to determine the relations of suspended-solids concentration to ABS and suspendedsolids concentration to turbidity at the North Fork and Speedy Point sites. For samples used in regression analyses, measured suspended-solids concentrations at the North Fork and Speedy Point sites ranged from 3 to 37 milligrams per liter, and organic content ranged from 50 to 83 percent. Corresponding salinity for these samples ranged from 0.12 to 22.7 parts per thousand, and corresponding temperature ranged from 19.4 to $31.8^{\circ} \mathrm{C}$. Relations determined using this technique are site specific and only describe suspended-solids concentrations at locations where data were collected. The suspended-solids concentration to ABS relation resulted in correlation coefficients of 0.78 and 0.63 at the North Fork and Speedy Point sites, respectively. The suspended-solids concentration to turbidity relation resulted in correlation coefficients of 0.73 and 0.89 at the North Fork and Speedy Point sites, respectively. The adequacy of the empirical equations seems to be limited by the number and distribution of suspended-solids samples collected throughout the expected concentration range at the
North Fork and Speedy Point sites. Additionally, the ABS relations for both sites seem to overestimate at the low end and underestimate at the high end of the concentration range.

Based on the sensitivity analysis, temperature had a greater effect than salinity on estimated suspended-solids concentrations. Temperature also appeared to affect ABS data, perhaps by changing the absorptive and reflective characteristics of the suspended material. Salinity and temperature had no observed effects on the turbidity relation at the North Fork and Speedy Point sites.

Estimates of suspended-solids concentrations using ABS data were less "erratic" than estimates using turbidity data. Combining ABS and turbidity data into one equation did not improve the accuracy of results, and therefore, was not considered.

\section{Introduction}

The Indian River Lagoon extends about 156 mi along the central-east coast of Florida. The St. Lucie River Estuary is a major tributary at the southern end of the lagoon (fig. 1). Drainage modifications and increased land use in the St. Lucie watershed have substantially increased wet-season flows and reduced dry-season flows entering the estuary. Anthropogenic alterations have caused a high volume of stormwater discharges, producing large salinity fluctuations and sedimentation rates. The transport of these sediments as suspended load decreases light penetration with increased turbidity, and deposition of the sediments creates layers of fine-grained, nutrient-rich muck within the estuary. These processes have contributed to detrimental effects to the seagrass communities and overall health of the estuarine system. To restore and protect environmental resources of the Indian River Lagoon and the St. Lucie River Estuary, the South Florida Water Management District (SFWMD) and the St. Johns Water Management District (SJWMD) initiated the Indian River Lagoon SurfaceWater Improvement and Management (SWIM) Plan (Steward and others, 1993). 


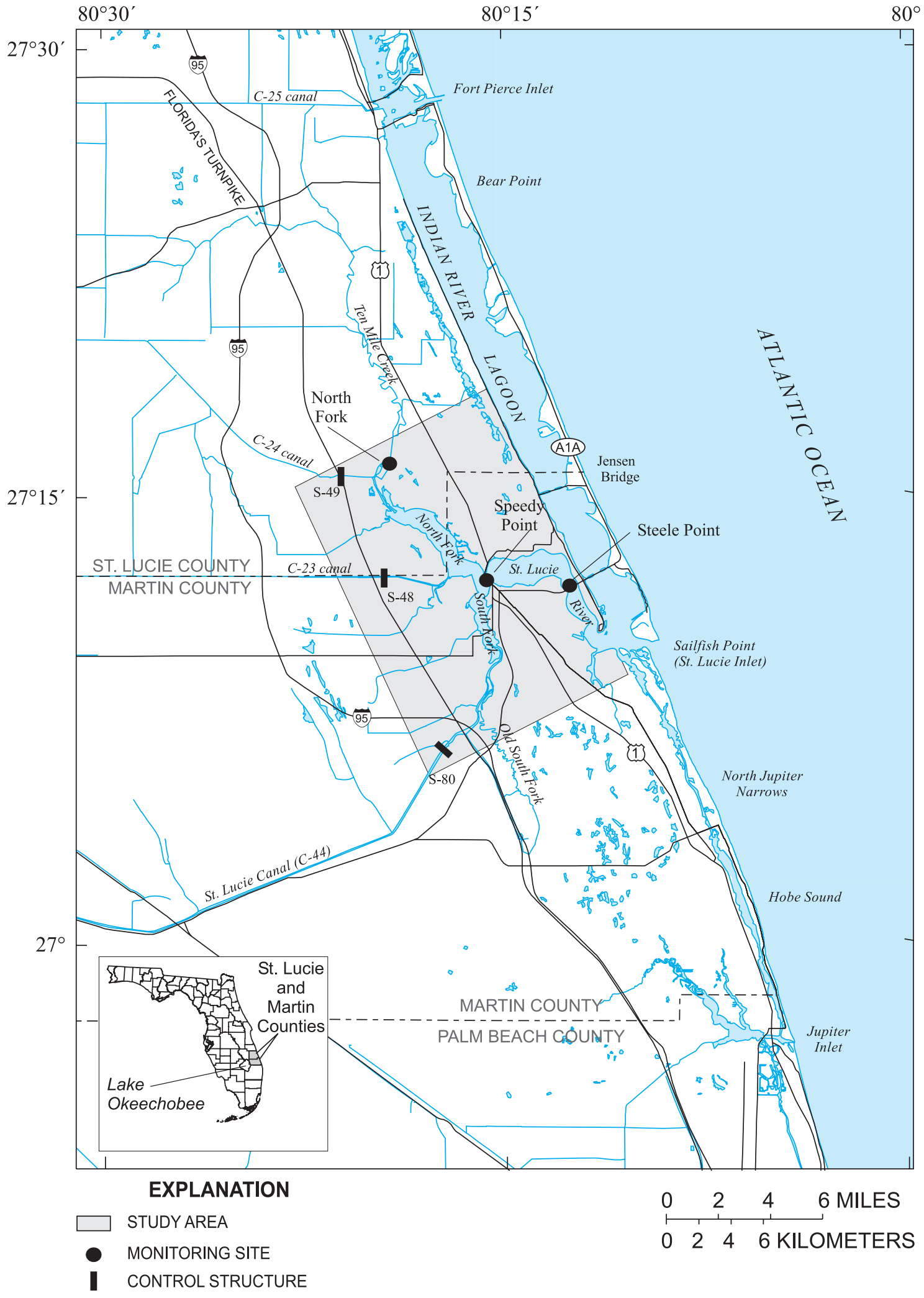

Figure 1. Location of monitoring sites in the St. Lucie River Estuary study area. 
Improving techniques to calculate sediment loads in these environments on a continuous basis will increase the accuracy of records and enhance the overall understanding of the estuarine system. Specifically, managers need to accurately determine suspended-solids loads entering the estuary, suspended-solids transport and deposition characteristics within the estuary, and the relation of suspended-solids transport to tidal flows and freshwater inflows. In 1999, the U.S. Geological Survey (USGS), in cooperation with the SFWMD, began an investigation to test the use of data from acoustic and optic instruments as surrogates for the estimation of suspendedsolids concentrations. Turbidity sensors were installed at an existing flow and salinity monitoring network in the St. Lucie River Estuary system where acoustic instruments were already in place. Water samples were collected to determine suspended-solids concentrations at the North Fork, Speedy Point, and Steele Point monitoring sites (fig. 1). The existing monitoring network is the result of a cooperative effort between the USGS and SFWMD to provide hydrologic and water-quality data for the estuary.

\section{Purpose and Scope}

This report describes the feasibility of using acoustic and optic methods to improve the accuracy of estimating highly organic suspended-solids concentrations in the St. Lucie River Estuary. Acoustic backscatter strength (ABS), turbidity, salinity, and temperature data are presented and analyzed, as well as data from water samples collected for laboratory determination of suspended-solids concentrations. Regression analyses are performed to determine the suspended-solids concentration to ABS relation and the suspended-solids concentration to turbidity relation. Empirical and site-specific estimation models are presented for suspended-solids concentrations using time-series data from acoustic and optic instruments. Relations between point and mean cross-sectional suspended-solids concentrations also are addressed as a necessary step for calculating time series of mean suspended-solids concentrations.

\section{Description of Study Area}

The St. Lucie River Estuary supports a large variety of plants and animals including seagrass, marine fish, and invertebrates. The estuary is located in parts of Martin and St. Lucie Counties and has two major forks - the North Fork and the South Fork (South Florida Water Management District, 1999, p. 2). Five tributaries to the estuary provide drainage for a watershed that encompasses about $820 \mathrm{mi}$. Ten Mile Creek is a major tributary to the North Fork; the C-23 and C-24 canals drain agricultural and residential lands and discharge freshwater into the estuary through control structures S-48 and S-49; Old South Fork is a major tributary to the South Fork; and St. Lucie Canal (C-44) connects Lake Okeechobee to the South Fork (fig. 1). The St. Lucie Canal also provides drainage for agricultural lands and Lake Okeechobee through a series of gated spillways and a lock chamber (for boat traffic) at structure S-80.
The study was conducted at three monitoring sites representing different flow magnitudes, water-quality, and channel cross-sectional characteristics. The North Fork site is just north of Kellstadt Bridge along Port St. Lucie Boulevard in southern St. Lucie County; the Speedy Point site is beneath Roosevelt Bridge along U.S. Highway 1 in northern Martin County; and the Steele Point site is beneath Evans Crary Bridge along the coast in northern Martin County (fig. 1)

\section{Acknowledgments}

The authors are grateful to Gordon Hu from the SFWMD for his input throughout the study. Special thanks is extended to the SFWMD staff at the Martin/St. Lucie Service Center for use of their facilities.

\section{Methods of Investigation and Data Analysis}

Instrument installation and field data collection and analysis were performed similarly at the North Fork, Speedy Point, and Steele point monitoring sites. Data collected at the Steele Point site, however, could not be used in the analysis because multiple instrument relocations due to bridge construction resulted in inconsistent data. All field data except suspended-solids concentration were recorded at 15-minute intervals. Water samples for determination of suspended-solids concentration were collected on a monthly and event-driven basis. A typical instrument setup for water sampling at the monitoring sites in the St. Lucie River Estuary is shown in figure 2 .

\section{Measurement of Acoustic Backscatter Strength}

Acoustic Doppler velocity meter (ADVM) instruments were used to measure an index of the mean water velocity at the monitoring sites and to collect data pertaining to the ABS received by the sensor. The instruments were placed at a fixed location vertically (about middepth) and measured a section about $19 \mathrm{ft}$ in length, between 6 and $25 \mathrm{ft}$ from the ADVM transducer faces. The ADVM produces a short pulse of sound at a known frequency, which is reflected (scattered) in all directions by particulate matter in the water. The acoustic return signal received by the ADVM has a frequency change (Doppler shift) proportional to the velocity of the scattering material (SonTek, 1997). The water velocity measured by the ADVM represents an index velocity that has a direct relation to the mean channel velocity.

$\mathrm{ABS}$ is a measure of the strength of acoustic return signals reflected from material in suspension within the body of water measured, and is reported in counts. The St. Lucie River Estuary is an environment that promotes extensive biological growth on all submerged structures, including the instruments at the monitoring sites. Biofouling of the 


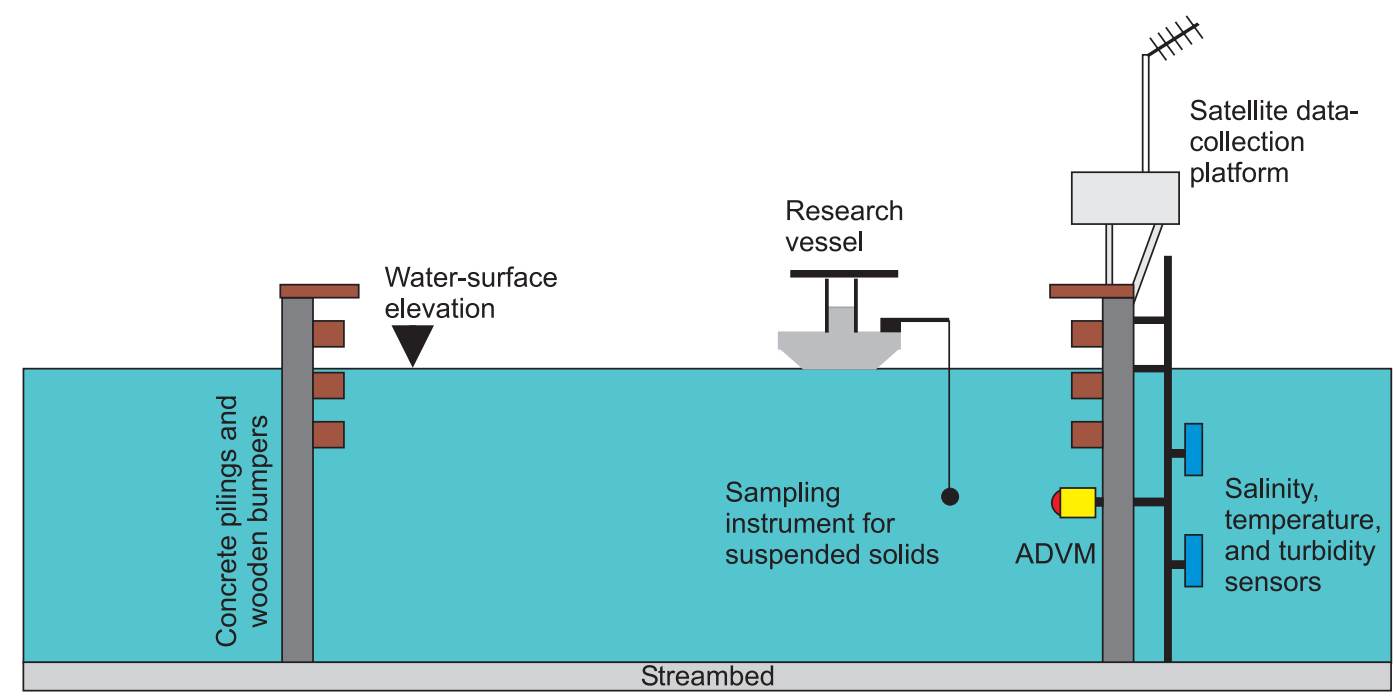

Figure 2. Instrument setup for the monitoring sites in the St. Lucie River Estuary. transducer faces of the ADVM can substantially affect ABS measurements, and periodic cleaning of transducer faces is necessary to maintain accuracy. Corrections can be used to account for decreasing signal strength due to biological growth, but these connections usually decrease the accuracy of the estimates, as described later for the North Fork site.

\section{Measurement of Turbidity}

Turbidity was measured at two depths at the Speedy Point site to document any vertical stratification in the distribution of suspended solids, and at only one depth at the North Fork site because the stream at this site appears to be well mixed. Turbidity is recorded in nephelometric turbidity units (NTU), which is a measure of suspended-solids content (cloudiness) in water. Instruments used in this study measure turbidity by projecting a light beam into a volume of water and then measuring the light scattered off suspended particles present in the water (YSI Incorporated, 1998). Biofouling was observed on turbidity and salinity probes (fig. 3); therefore, frequent field visits for instrument maintenance and calibration were necessary.

\section{Sampling and Determination of Suspended- Solids Concentrations}

Water samples were collected to represent local and mean cross-sectional suspended-solids concentrations using point and depth-integrated (top to bottom) sampling techniques. Local space, in this report, represents an area that is at the altitude of the ADVM transducer and about $9 \mathrm{ft}$ from the transducer toward the center of the stream. Local suspendedsolids concentrations were measured by collecting water samples using a horizontal Van Dorn bottle type sampler. Cross-sectional concentrations were measured by collecting depth-integrated samples using the equal discharge increment method (EDI) and the DH-59 sampler as described by the U.S. Interagency Committee on Water Resources, Subcommittee on Sedimentation (1965). The two samplers used in the study are shown in figure 4 . All water samples were collected in accordance with USGS prescribed methods (Edwards and Glysson, 1988). Collection of a water sample using the DH-59 sampler is depicted in figure 5 .

Traditional laboratory techniques used in the determination of total suspended-solids concentrations were modified to address potential bias in the results as compared to those used for suspended-sediment concentration analyses (Gray and others, 2000). Analyses performed at the USGS Ocala Laboratory in Florida were modified to process: (1) entire water samples rather than aliquots from samples; and (2) all bottles from depth-integrated cross-sectional samples. The suspendedsolids concentrations were obtained by drying sample contents at $105{ }^{\circ} \mathrm{C}$. The volatile component was determined by baking the contents at $500{ }^{\circ} \mathrm{C}$ and subtracting the inorganic residue from the suspended-solids concentration value. To avoid misinterpretation, laboratory results are presented as suspendedsolids concentrations in this report.

\section{Collection of Tidal Stage, Discharge, Salinity, and Temperature Data}

Tidal stage, salinity, and temperature data were collected in 15-minute intervals at the North Fork and Speedy Point sites, and miscellaneous discharge measurements were taken for velocity calibrations and rating development. All 15-minute data were recorded and transmitted every 4 hours by way of Geostationary Operational Environmental Satellite (GOES) into the USGS National Water Information System (NWIS) database. A monitoring site (Steele Point) in the St. Lucie River Estuary is shown in figure 6. 


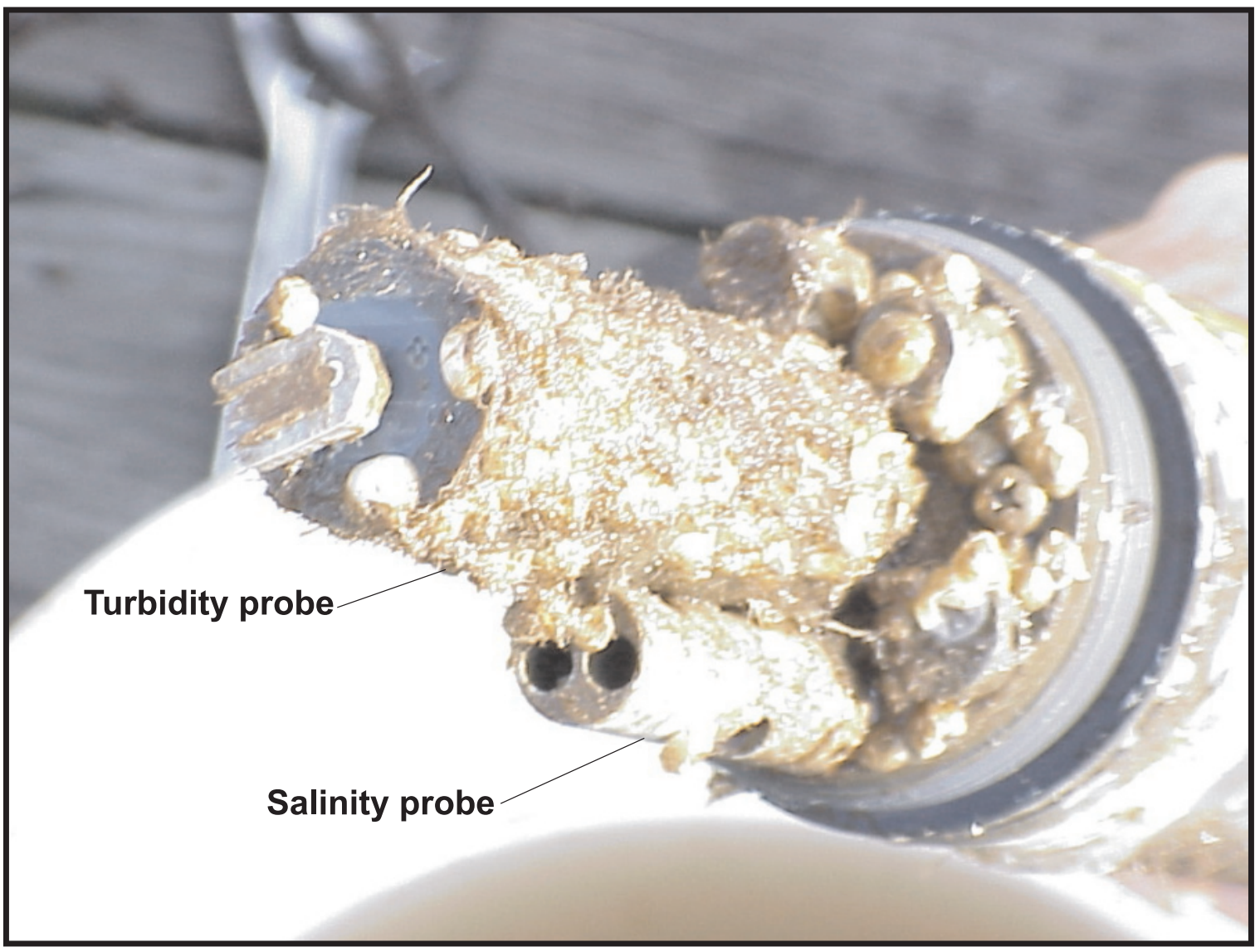

Figure 3. Extent of biofouling of turbidity and salinity probes between field maintenance visits at a monitoring site in the St. Lucie River Estuary.

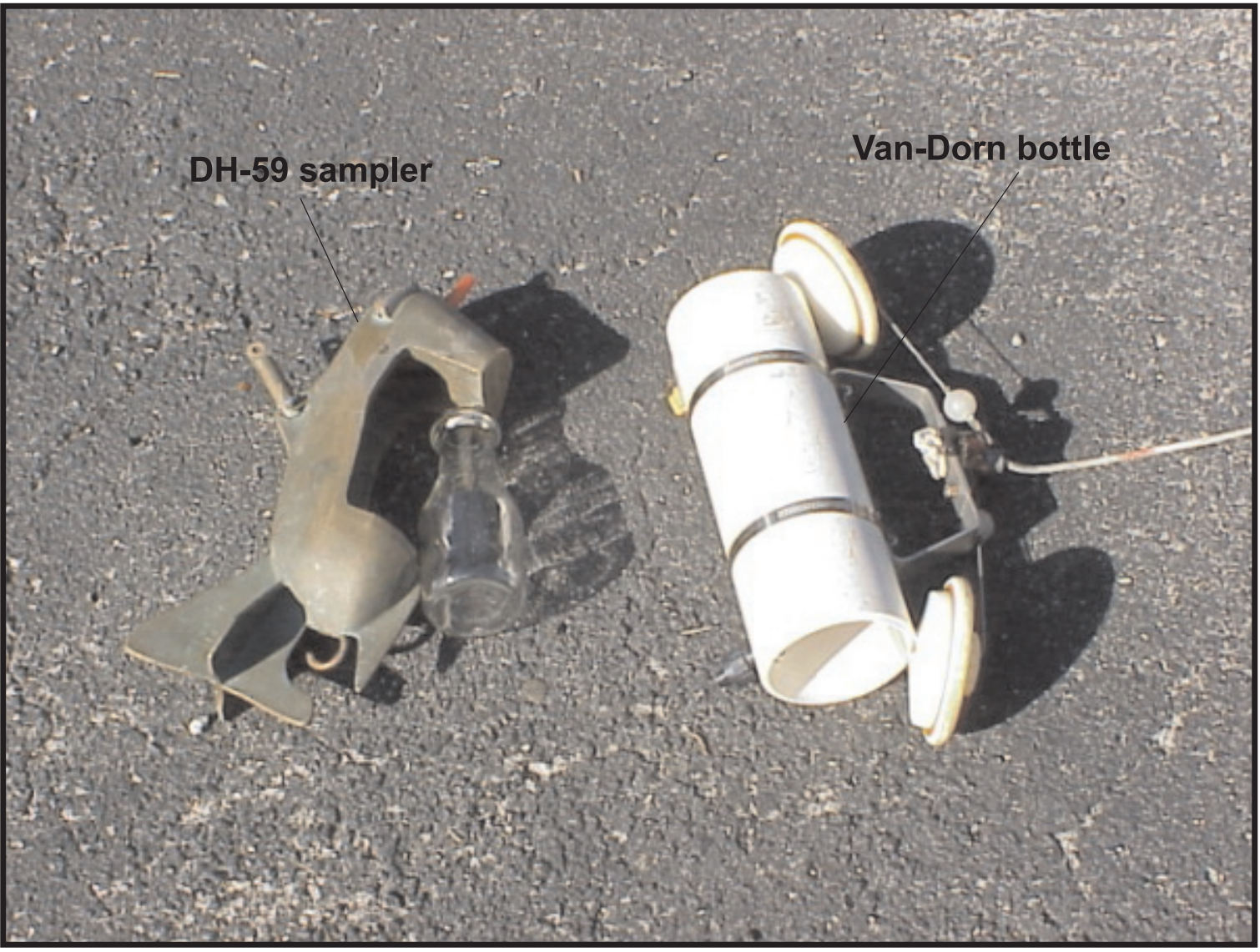

Figure 4. Sampling equipment used for suspended-solids measurements. 


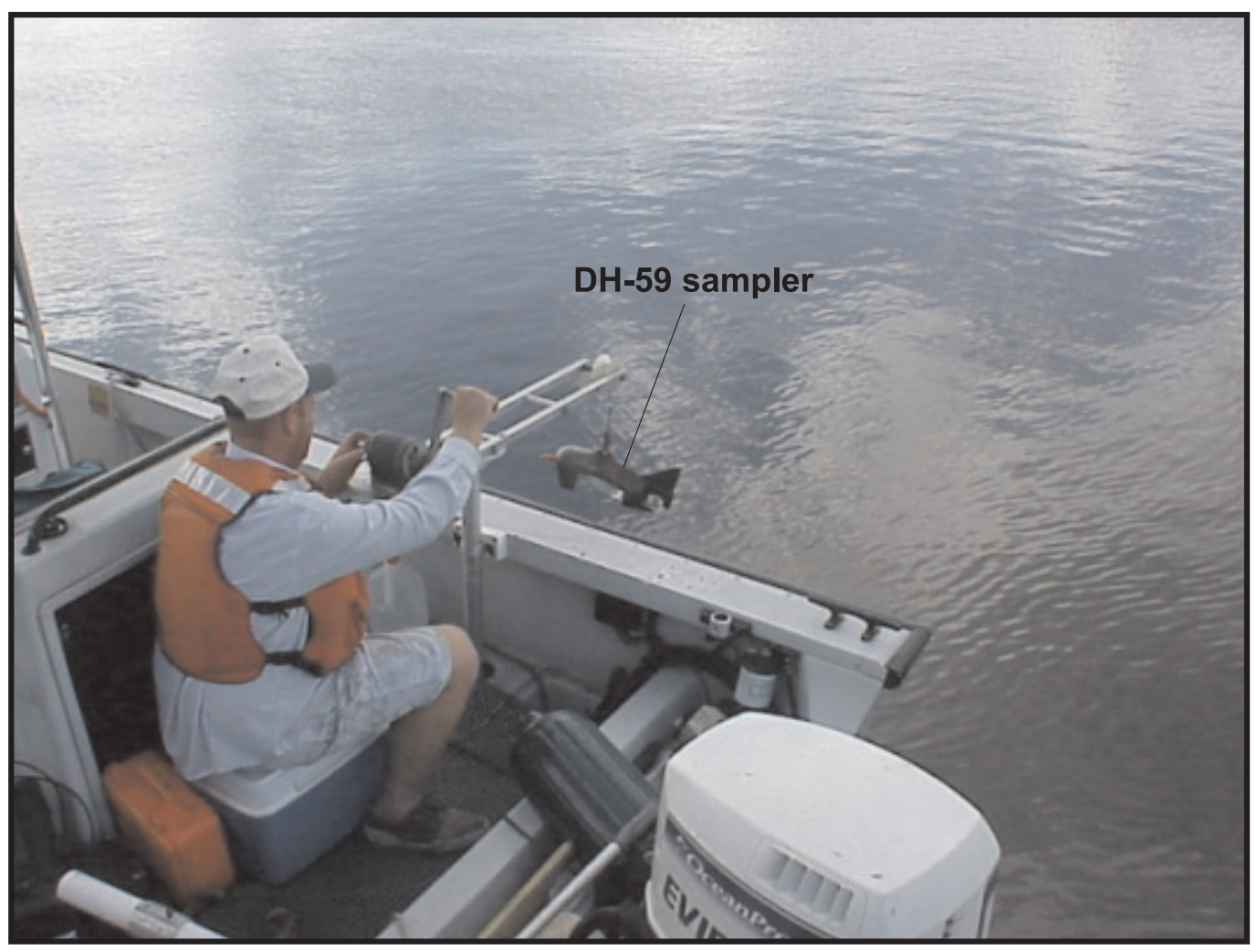

Figure 5. Collection of an integrated (top to bottom) water sample for suspendedsolids concentration analysis.

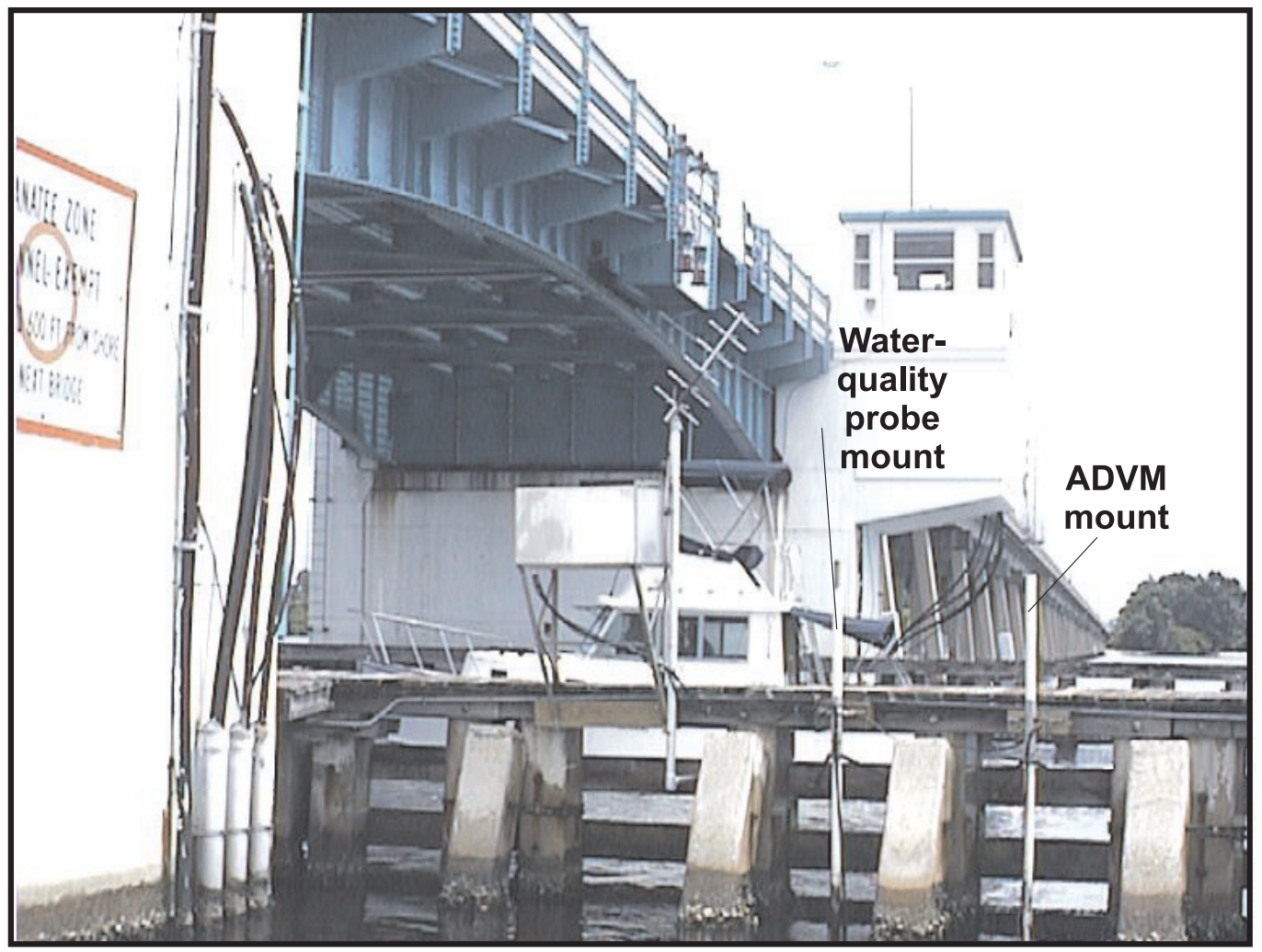

Figure 6. A monitoring site (Steele Point) in the St. Lucie River Estuary. ADVM is acoustic Doppler velocity meter. 
Tidal stage data were recorded to determine water depth and to calculate the stage-dependent cross-sectional area needed for discharge computations. These data were collected using an incremental shaft encoder attached to a pulley that suspends a stainless-steel tape, weight, and float inside an 8-in-diameter polyvinyl chlorinated (PVC) pipe stilling well.

Discharge measurements were performed using a boatmounted acoustic Doppler current profiler (ADCP). From these measurements, velocity ratings were developed to compute time-series records of discharge at the monitoring sites.

Salinity and temperature were recorded as water-quality characteristics to determine changes in water density. Because water density directly affects the speed and absorption of sound, density changes within the volume of water measured by the ADVM can affect the velocity and ABS values reported by the instrument.

\section{Analysis of Laboratory and Field Data}

As previously mentioned, suspended-solids concentration was determined at the USGS Ocala Laboratory, and temperature and salinity were determined in the field. Suspendedsolids concentrations for samples used in regression analyses (described later) ranged from 3 to $37 \mathrm{mg} / \mathrm{L}$, and organic content ranged from 50 to 83 percent. The suspended-solids concentrations and organic content varied depending on the monitoring site location and flow conditions at the time of sampling. Observed data suggest that no substantial temperature stratification occurs at the monitoring sites, and substantial salinity stratification occurs only during large freshwater releases from structures S-48, S-49, and S-80 along the C-23, C-24, and C-44 canals, respectively (fig. 1). For the samples just mentioned, corresponding salinity ranged from 0.12 to $22.7 \mathrm{ppt}$ depending on the magnitude and duration of freshwater releases from structures $\mathrm{S}-48, \mathrm{~S}-49$, and S-80; water temperature ranged from 19.4 to $31.8{ }^{\circ} \mathrm{C}$.

\section{Estimation of Suspended-Solids Concentrations Using Acoustic and Optic Methods}

The collection of water samples for the computation of suspended-solids transport is a labor intensive and costly process. Additionally, no direct correlation exists between suspended-solids concentration and discharge in tidal streams; the magnitude and chemical composition of freshwater inflow affect suspended-solids concentration because of flocculation of dissolved organics. For these reasons, it is advantageous to have a reliable method for estimating suspended-solids concentration using surrogate parameters. Measuring surrogate parameters such as ABS and turbidity, and developing relations between these and suspended-solids concentration, can improve the accuracy of suspended-solids transport estimates as well as increase temporal resolution of the data by allowing for the computation of time-series records.

The equations used in this study to test the feasibility of using ABS and turbidity data to estimate suspended-solids concentrations are as follows:

$$
\begin{gathered}
\text { Suspended solids }=10 \mathrm{ABS}[\mathrm{a}+\mathrm{b} \log (\text { salinity }) \\
+\mathrm{c} \log (\text { temperature })]+\mathrm{d}
\end{gathered}
$$

and

$$
\text { Suspended solids }=\mathrm{a}^{\prime} \text { Turbidity }+\mathrm{b}^{\prime} \text {, }
$$

where $a, b, c, d, a^{\prime}$, and $b^{\prime}$ are regression coefficients, and ABS, salinity, temperature, and turbidity are field measured parameters. Equation 1 is exponential because acoustic data are reported in counts (a logarithmic, internal instrument unit), and regression analyses using $\mathrm{ABS}$ data must be performed with all raw linear data converted to a logarithmic scale.

The use of ABS and turbidity data collected at the monitoring sites in the St. Lucie River Estuary for estimating suspended-solids concentrations with equations 1 and 2 is summarized herein. A description of obtained ABS and turbidity relations is followed by a discussion on the quality of empirical equations and a sensitivity analysis describing the response that each relation shows to certain field parameters. Combining ABS and turbidity data into one equation did not improve the accuracy of results, and therefore, is not used nor described herein. A sample of time-series estimates of suspended-solids concentrations also is presented. The computation of suspended-sediment transport (loads) is not presented because of pending verification of estimating equations used in the study and the large amount of missing or insufficient field data.

\section{Suspended-Solids Concentration to Acoustic Backscatter Strength Relation}

Multivariable regression techniques were used to determine the best possible relation of suspended-solids concentration to ABS at the North Fork and Speedy Point sites. Salinity and temperature were included in the empirical equations to account for the effects of density change.

\section{North Fork Site}

At the North Fork site, 38 of 49 collected water samples were used to determine the relation of suspended-solids concentration to ABS in the local space. All data collected at this site and used for the regression analysis are presented in table 1. Eleven samples were not used because of missing, bad, or erroneously collected ABS data. The measured suspended-solids concentrations for water samples used in this analysis ranged from 3 to $18 \mathrm{mg} / \mathrm{L}$, and corresponding average salinity and temperature ranged from 0.2 to $12.9 \mathrm{ppt}$ and 19.4 
Table 1. Point sample data from the North Fork site used for regression analyses.

[Values shown in bold red were used to determine the suspended solids to acoustic backscatter relation and the suspended solids to turbidity relation. ABS, acoustic backscatter strength; NTU, nephelometric turbidity units; BD, bad data; MD, missing data]

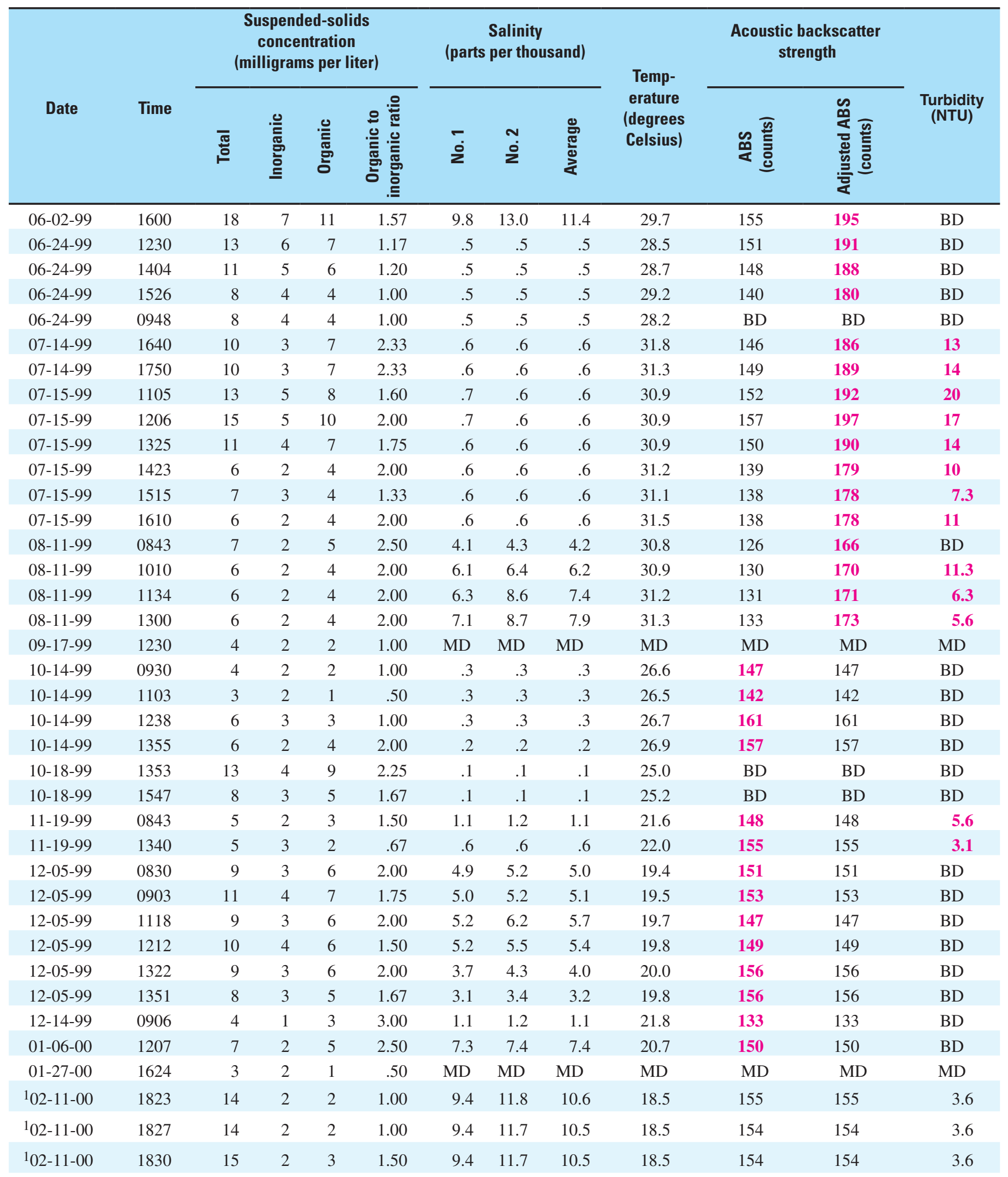


Table 1. Point sample data from the North Fork site used for regression analyses. (Continued)

[Values shown in bold red were used to determine the suspended solids to acoustic backscatter relation and the suspended solids to turbidity relation. ABS, acoustic backscatter strength; NTU, nephelometric turbidity units; BD, bad data; MD, missing data]

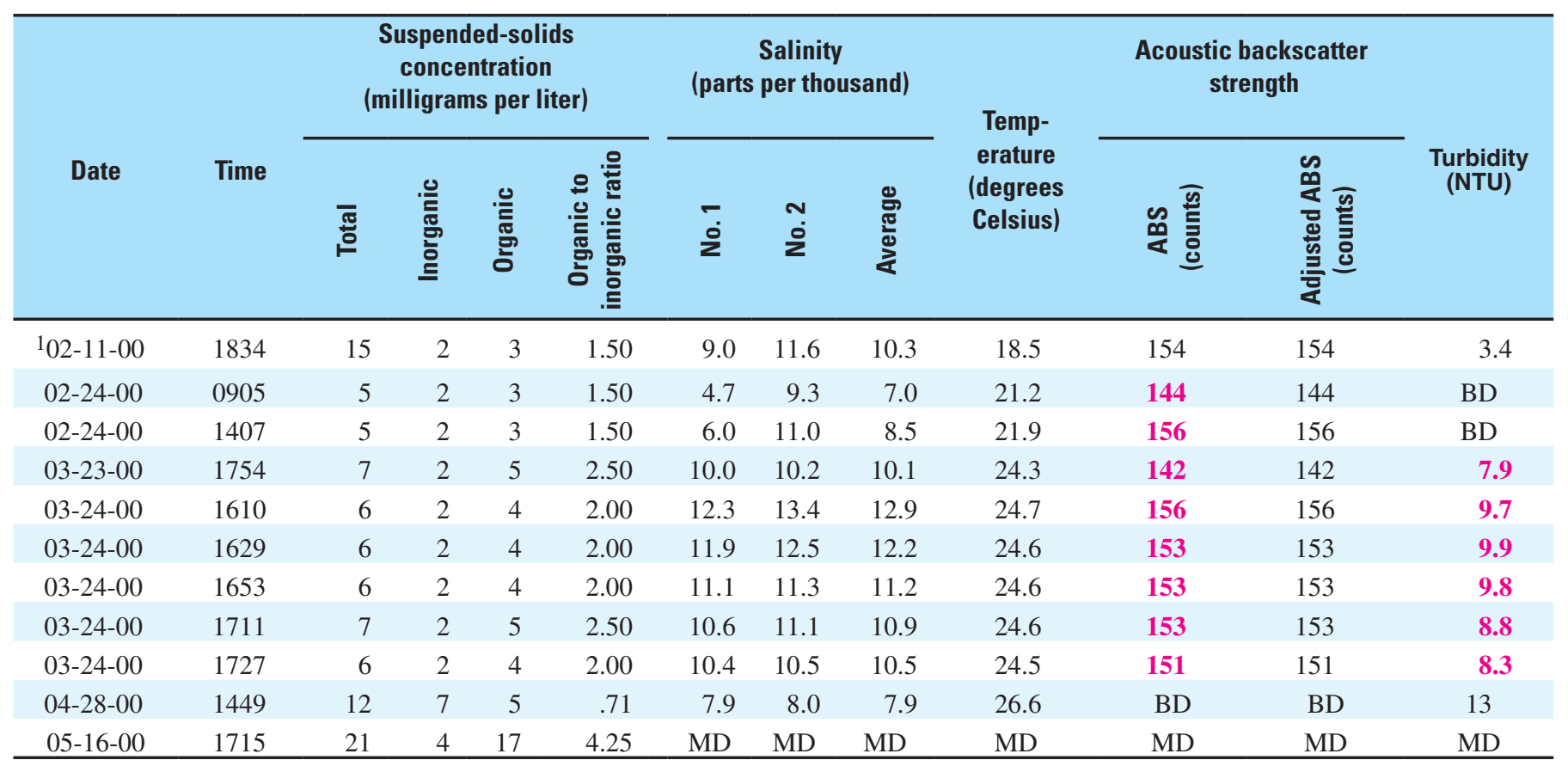

${ }^{1}$ Data from this sample were not used in the regression analysis because they were erroneously collected outside of local space at the North Fork site; data are shown solely for documentation.

to $31.8^{\circ} \mathrm{C}$, respectively. All ABS data collected from June 2 to August 11,1999, had to be adjusted by correcting recorded ABS values based on the difference between readings before and after cleaning the transducers. ABS readings increased by 40 counts after transducers were cleaned in August 1999. A constant correction was applied because there is no available information to determine a correction prorated between the time biofouling started and the instrument cleaning date.

Because density affects the speed of sound in water, salinity and temperature were both included in the multivariable regression analysis used to determine the best possible relation of suspended-solids concentration to ABS. This empirical relation is expressed as:

$$
\begin{gathered}
\text { Suspended solids }=10^{\mathrm{ABS}}[0.02876+0.00032 \log (\text { salinity }) \\
-0.01106 \log (\text { temperature })]-1.30367 .
\end{gathered}
$$

The correlation coefficient is:

$$
\mathrm{R}^{2}=0.78
$$

The relation obtained between measured and estimated suspended-solids concentrations using equation 3 is shown in figure 7. The one-to-one line shown figure 7 does not represent a regression line of suspended-solids concentrations as a function of ABS because estimated suspended-solids concentrations are a function of temperature and salinity as well as ABS. This plot shows actual measured suspended-solids concentrations relative to estimated concentrations in order to depict how well equation 3 fits measured concentrations at the North Fork site.

\section{Speedy Point Site}

At the Speedy Point site, 33 of 42 collected water samples were used to determine the relation of suspended-solids concentration to ABS in the local space. All data collected at this site and used in the regression analysis are presented in table 2. Nine samples were not used in the regression analysis because of missing or bad ABS data or because of questionable suspended-solids sample data. The measured suspendedsolids concentrations for samples used in this analysis ranged from 4 to $23 \mathrm{mg} / \mathrm{L}$, with corresponding average salinity and temperatures ranging from 0.2 to $22.7 \mathrm{ppt}$ and 20.7 to $31.8^{\circ} \mathrm{C}$, respectively. No corrections to ABS data were necessary at the Speedy Point site. The empirical equation developed for estimating suspended-solids concentrations at this site is expressed as:

$$
\begin{gathered}
\text { Suspended solids }=10^{\mathrm{ABS}}[0.03247-0.00204 \log (\text { salinity }) \\
-0.01547 \log (\text { temperature })-0.23927 .
\end{gathered}
$$

The correlation coefficient is:

$$
\mathrm{R}^{2}=0.63
$$




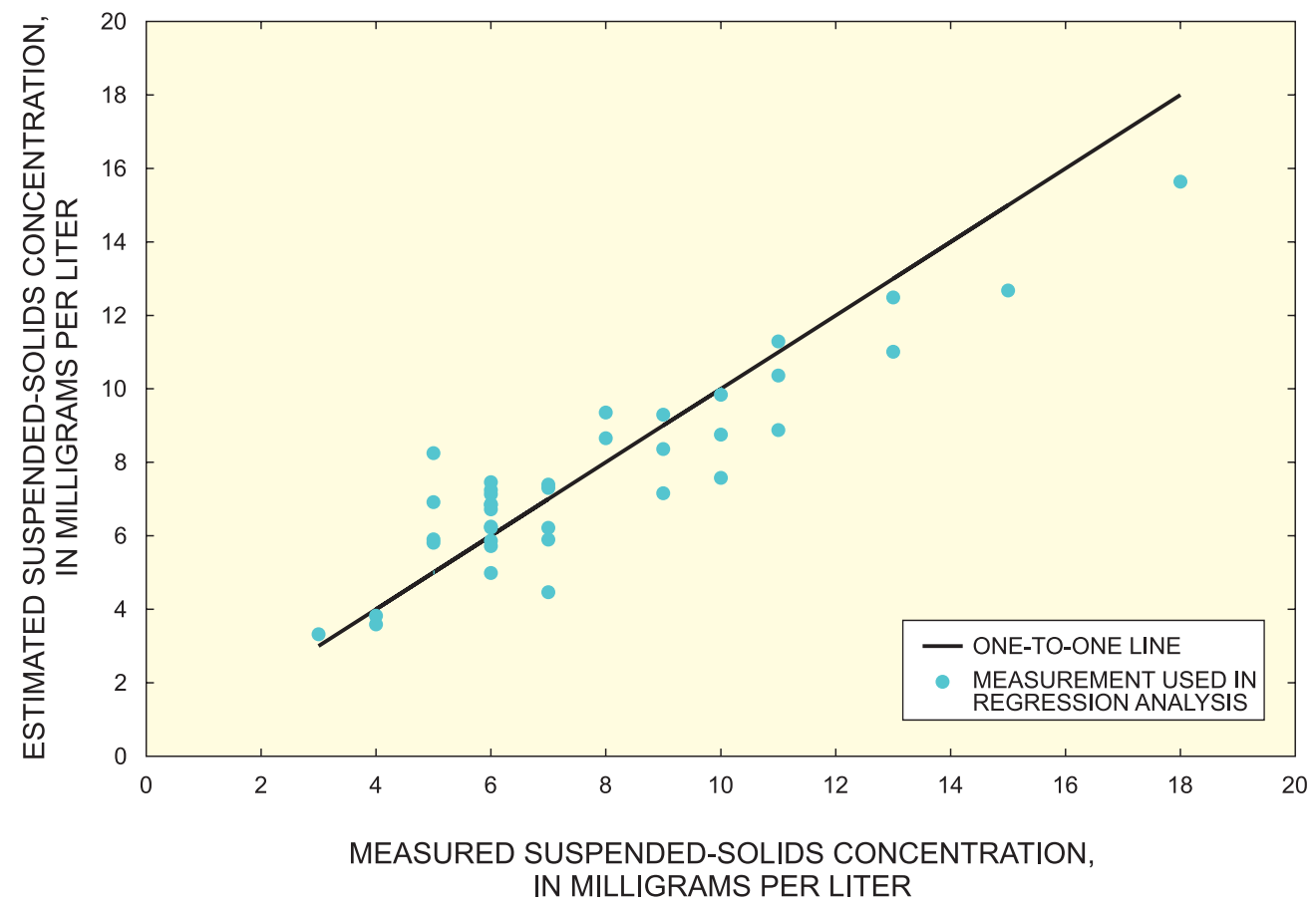

Figure 7. Measured to estimated suspended-solids concentration relation at the North Fork site using acoustic backscatter strength data.

Table 2. Point sample data from the Speedy Point site used for regression analyses.

[Values in bold red were used to determine the suspended solids to acoustic backscatter relation and the suspended solids to turbidity relation. MD, missing data; $\mathrm{BD}$, bad data]

\begin{tabular}{|c|c|c|c|c|c|c|c|c|c|c|c|c|c|c|c|}
\hline Date & Time & \multicolumn{4}{|c|}{$\begin{array}{c}\text { Suspended-solids } \\
\text { concentration } \\
\text { (milligrams per liter) }\end{array}$} & \multicolumn{3}{|c|}{$\begin{array}{c}\text { Salinity } \\
\text { (parts per thousand) }\end{array}$} & \multicolumn{3}{|c|}{$\begin{array}{c}\text { Temperature } \\
\text { (degrees Celsius) }\end{array}$} & 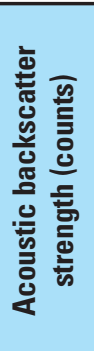 & \multicolumn{3}{|c|}{$\begin{array}{c}\text { Turbidity } \\
\text { (nephelometric } \\
\text { turbidity units) }\end{array}$} \\
\hline 06-03-99 & 0915 & 5 & 2 & 3 & 1.5 & $\mathrm{MD}$ & MD & MD & $\mathrm{MD}$ & $\mathrm{MD}$ & MD & MD & MD & MD & MD \\
\hline 06-24-99 & 0920 & 8 & 3 & 5 & 1.7 & 3.4 & 6.3 & 4.9 & 29.3 & 29.4 & 29.4 & 154 & 8.9 & 8.8 & 8.85 \\
\hline 06-24-99 & 1118 & 10 & 4 & 6 & 1.5 & 2.5 & 3.1 & 2.8 & 29.4 & 29.4 & 29.4 & 145 & 8.1 & 7.2 & 7.65 \\
\hline 06-24-99 & 1200 & 10 & 4 & 6 & 1.5 & 2.4 & 2.9 & 2.6 & 29.4 & 29.3 & 29.4 & 151 & 8.1 & 6.8 & 7.45 \\
\hline 06-24-99 & 1332 & 10 & 4 & 6 & 1.5 & 2.1 & 2.3 & 2.2 & 29.6 & 29.5 & 29.6 & 142 & 9.9 & 7.5 & 8.7 \\
\hline 07-14-99 & 1711 & 14 & 6 & 8 & 1.3 & 6.0 & 6.6 & 6.3 & 31.9 & 31.6 & 31.8 & 153 & 8.5 & 13.0 & 10.75 \\
\hline 07-15-99 & 1020 & 6 & 2 & 4 & 2.0 & 8.7 & 10.1 & 9.4 & 30.8 & 30.7 & 30.8 & 146 & 4.5 & 16.0 & 10.25 \\
\hline 07-15-99 & 1134 & 6 & 2 & 4 & 2.0 & 9.4 & 9.5 & 9.4 & 30.9 & 30.8 & 30.9 & 151 & 5.1 & 15.0 & 10.05 \\
\hline 07-15-99 & 1259 & 6 & 2 & 4 & 2.0 & 10.1 & 9.2 & 9.7 & 31.7 & 31.6 & 31.7 & 133 & 5.0 & 11.0 & 8.00 \\
\hline
\end{tabular}


Table 2. Point sample data from the Speedy Point site used for regression analyses. (Continued)

[Values in bold red were used to determine the suspended solids to acoustic backscatter relation and the suspended solids to turbidity relation. MD, missing data; $\mathrm{BD}$, bad data]

\begin{tabular}{|c|c|c|c|c|c|c|c|c|c|c|c|c|c|c|c|}
\hline \multirow{2}{*}{ Date } & \multirow{2}{*}{ Time } & \multicolumn{4}{|c|}{$\begin{array}{c}\text { Suspended-solids } \\
\text { concentration } \\
\text { (milligrams per liter) }\end{array}$} & \multicolumn{3}{|c|}{$\begin{array}{c}\text { Salinity } \\
\text { (parts per thousand) }\end{array}$} & \multicolumn{3}{|c|}{$\begin{array}{c}\text { Temperature } \\
\text { (degrees Celsius) }\end{array}$} & \multirow{2}{*}{ 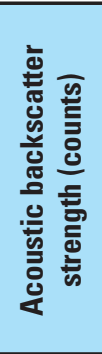 } & \multicolumn{3}{|c|}{$\begin{array}{c}\text { Turbidity } \\
\text { (nephelometric } \\
\text { turbidity units) }\end{array}$} \\
\hline & & 跑 & 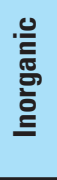 & 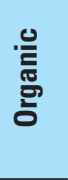 & 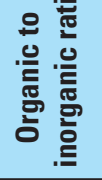 & No. 1 & No. 2 & 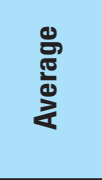 & No. 1 & No. 2 & 迆 & & No. 1 & No. 2 & 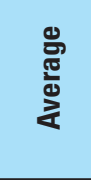 \\
\hline 07-15-99 & 1351 & 5 & 2 & 3 & 1.5 & 10.0 & 9.4 & 9.7 & 31.8 & 31.6 & 31.7 & 152 & 4.9 & 9.9 & 7.40 \\
\hline 07-15-99 & 1449 & 8 & 3 & 5 & 1.7 & 9.7 & 9.4 & 9.6 & 31.4 & 31.1 & 31.3 & 171 & 6.7 & 12.0 & 9.35 \\
\hline 07-15-99 & 1543 & 7 & 2 & 5 & 2.5 & 8.8 & 8.8 & 8.8 & 31.6 & 31.3 & 31.5 & 149 & 5.9 & 11.0 & 8.45 \\
\hline 08-11-99 & 0921 & 7 & 2 & 5 & 2.5 & 15.4 & 18.2 & 16.8 & 30.5 & 30.6 & 30.6 & 131 & 3.7 & 13.0 & 8.35 \\
\hline 09-17-99 & 1155 & 8 & 2 & 6 & 3.0 & MD & MD & MD & MD & MD & MD & MD & MD & MD & MD \\
\hline $10-14-99$ & 1125 & 18 & 6 & 12 & 3.5 & .2 & .2 & .2 & 27.0 & 27.0 & 27.0 & 133 & 13.0 & 18.0 & 15.50 \\
\hline $10-14-99$ & 1305 & 19 & 6 & 13 & 2.2 & .2 & .2 & .2 & 27.1 & 27.2 & 27.2 & 131 & 17.0 & 22.0 & 19.50 \\
\hline 10-14-99 & 1504 & 16 & 5 & 11 & 1.7 & .2 & .2 & .2 & 27.1 & 27.2 & 27.2 & 126 & 13.0 & 20.0 & 16.50 \\
\hline $10-14-99$ & 0956 & ${ }^{18}$ & ${ }^{14}$ & 14 & 6 & .2 & .2 & .2 & 27.1 & 27.1 & 27.1 & ${ }^{1} 126$ & 3.6 & 6.1 & ${ }^{1} 4.85$ \\
\hline $10-18-99$ & 1238 & 16 & 5 & 11 & 2.2 & .13 & .13 & .13 & 25.3 & 25.3 & 25.3 & $\mathrm{BD}$ & 15 & 16 & 15.5 \\
\hline 10-18-99 & 1505 & 13 & 3 & 10 & 3.3 & .12 & .12 & .12 & 26.0 & 25.9 & 26.0 & $\mathrm{BD}$ & 12 & 14 & 13 \\
\hline 11-19-99 & 0925 & 21 & 6 & 15 & 2.5 & 3.2 & 3.7 & 3.4 & 21.4 & 21.5 & 21.5 & 122 & 33 & 24 & 28.5 \\
\hline $02-24-00$ & 1246 & 18 & 5 & 13 & 2.6 & 22.5 & 22.3 & 22.4 & 20.7 & 20.7 & 20.7 & 153 & 16 & 22 & 19 \\
\hline $02-24-00$ & 1337 & 17 & 5 & 12 & 2.4 & 22.8 & 22.6 & 22.7 & 20.9 & 20.8 & 20.9 & 147 & 18 & 18 & 18 \\
\hline $03-23-00$ & 1617 & 9 & 3 & 6 & 2.0 & 19.0 & 19.7 & 19.4 & 24.3 & 24.4 & 24.4 & 131 & 6.8 & 13 & 9.9 \\
\hline $03-24-00$ & 1351 & 4 & 2 & 2 & 1.0 & 20.9 & 22.2 & 21.6 & 24.3 & 24.0 & 24.2 & 120 & 1.6 & 7.1 & 4.35 \\
\hline $03-24-00$ & 1457 & 5 & 2 & 3 & 1.5 & 20.4 & 22.2 & 21.3 & 24.2 & 23.9 & 24.1 & 122 & 2.2 & 8 & 5.1 \\
\hline $03-24-00$ & 1530 & 4 & 2 & 2 & 1.0 & 19.8 & 21.9 & 20.9 & 24.1 & 23.9 & 24.0 & 123 & 2.9 & 11 & 6.95 \\
\hline 04-14-00 & 1118 & 6 & 2 & 4 & 2.0 & 18.3 & 19.9 & 19.1 & 23.2 & 23.3 & 23.3 & 121 & 6.7 & 6.4 & 6.55 \\
\hline $04-28-00$ & 1300 & 32 & 10 & 22 & 2.2 & 4.8 & MD & MD & 25.9 & 25.8 & 25.9 & $\mathrm{BD}$ & 44 & 36 & 40 \\
\hline $04-28-00$ & 1323 & 37 & 11 & 26 & 2.4 & 4.9 & MD & MD & 26.0 & 25.7 & 25.9 & $\mathrm{BD}$ & 45 & 36 & 40.5 \\
\hline $05-04-00$ & 1246 & 20 & 7 & 13 & 1.9 & 4.2 & 4.7 & 4.5 & 24.8 & 24.7 & 24.8 & $\mathrm{BD}$ & 26 & 17 & 21.5 \\
\hline
\end{tabular}

${ }^{1}$ Questionable suspended-solids sample. The acoustic backscatter strength and turbidity data were not used in regression analyses and are shown here solely for documentation. 
The relation obtained between measured and estimated suspended-solids concentrations using equation 4 is shown in figure 8 . As in figure 7, the one-to-one line shown in figure 8 does not represent a regression line of suspended-solids concentrations as a function of ABS because estimated suspended-solids concentrations are a function of temperature and salinity as well as ABS. This plot shows actual measured suspended-solids concentrations relative to estimated concentrations in order to depict how well equation 4 fits measured concentrations at Speedy Point.

Erratic patterns in the acoustic data resulted in larger variance as compared to data collected at the North Fork site. Excessive turbulence within the volume of water measured by the instrument probably affected the consistency of ABS data. Turbulence develops at this site in the higher water velocity zones near the large concrete footings where instrumentation was installed. Observed flow patterns at the Speedy Point site and results obtained from correlation analyses suggest better results probably would have been obtained if instruments had been located in an area with less turbulence. Results obtained at the North Fork site also suggest that the technique used can provide better results under favorable measuring conditions.

\section{Suspended-Solids Concentration to Turbidity Relation}

Simple linear regression techniques were used to determine the best possible relation of suspended-solids concentration to turbidity at the North Fork and Speedy Point sites. Salinity and temperature had no observed effects on the turbidity relations.

\section{North Fork Site}

At the North Fork site, 20 of 49 collected water samples were used to determine the relation of suspended-solids concentration to turbidity in the local space (fig. 9). All turbidity data collected at this site and used for the regression analysis are presented in table 1. Twenty-nine water samples were not used in the regression analysis because of bad, missing, or erroneously collected turbidity data. The measured suspendedsolids concentrations for water samples used in this analysis ranged from 5 to $15 \mathrm{mg} / \mathrm{L}$, and corresponding average salinity and temperature ranged from 0.6 to $12.9 \mathrm{ppt}$ and 21.6 to $31.8^{\circ} \mathrm{C}$, respectively. The empirical equation developed for estimating suspended-solids concentrations using turbidity data at this site is expressed as:

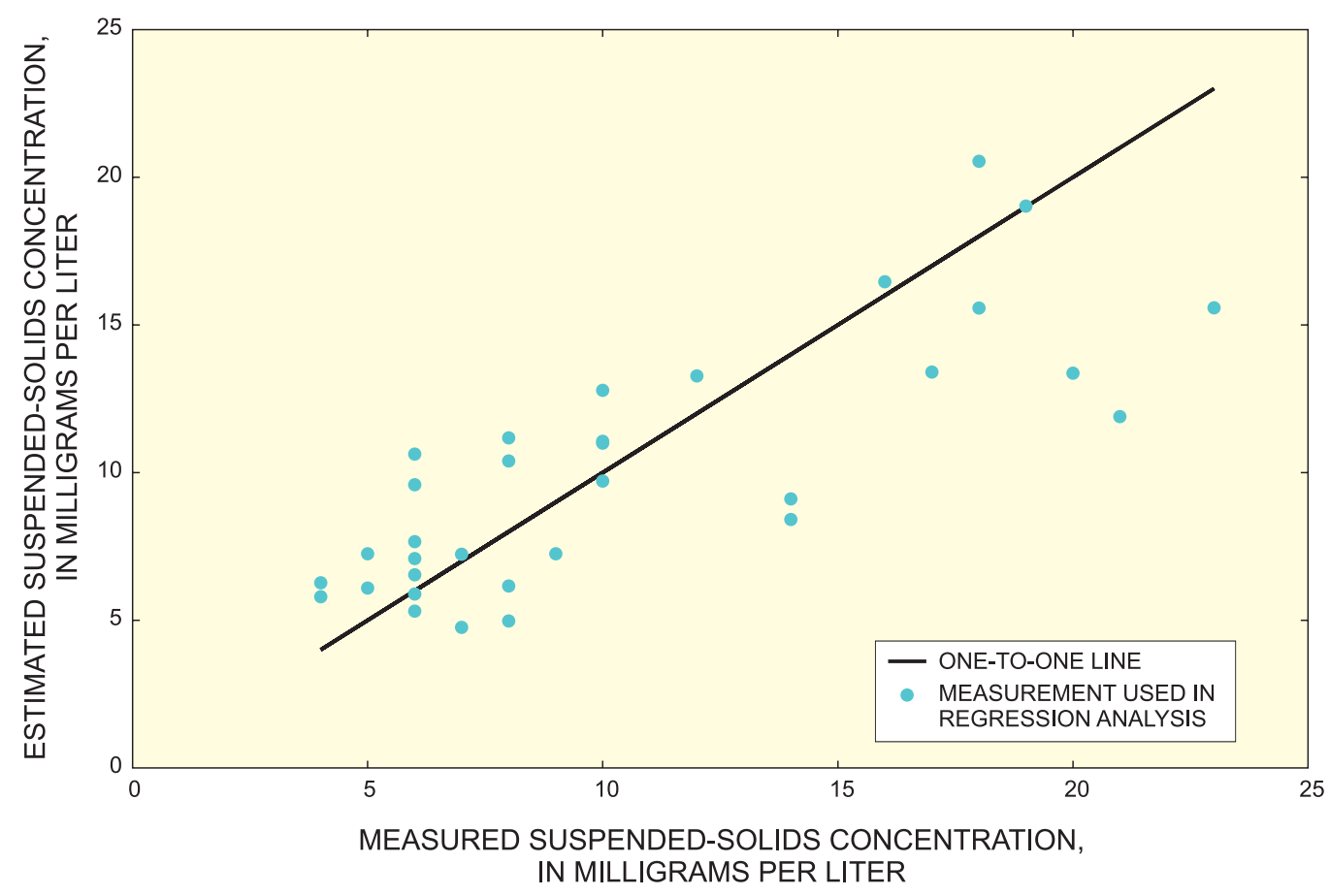

Figure 8. Measured to estimated suspended-solids concentration relation at the Speedy Point site using acoustic backscatter strength data. 


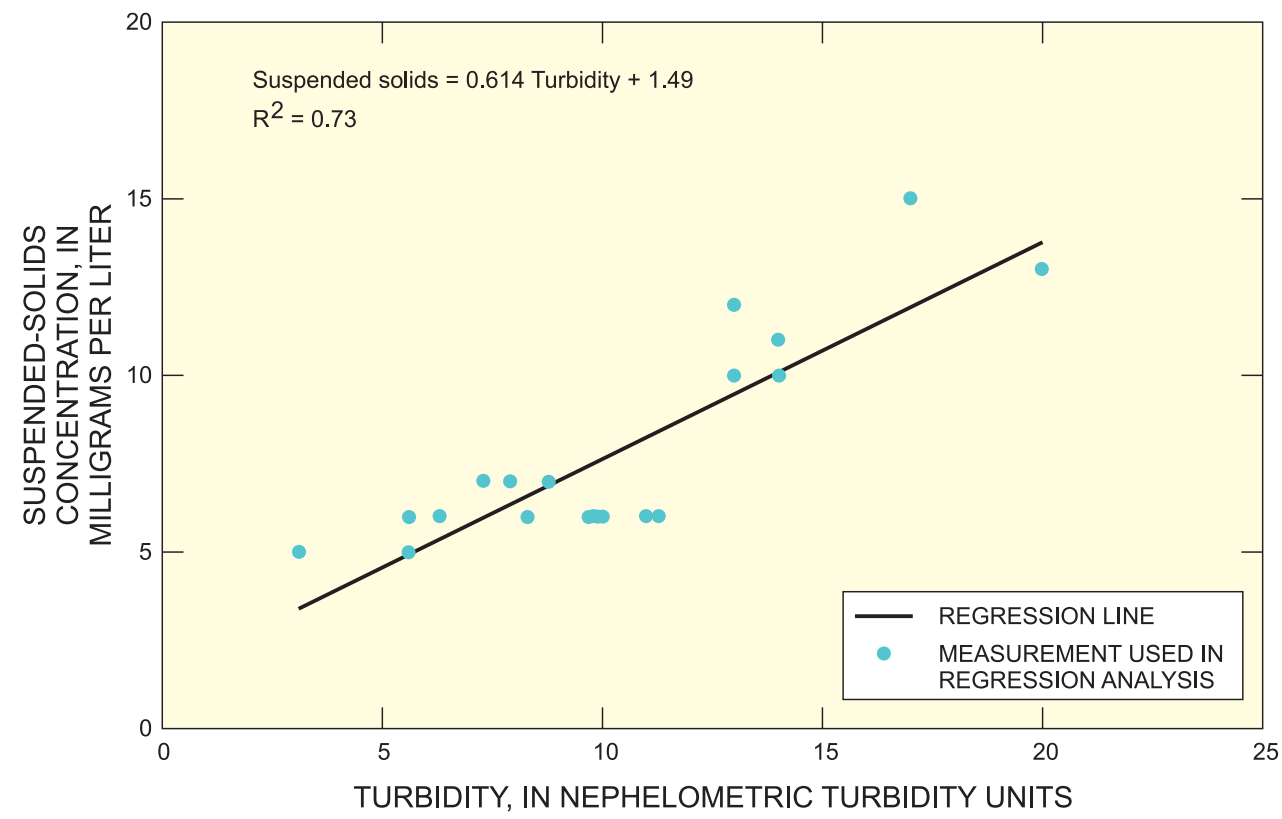

Figure 9. Suspended-solids concentration to turbidity relation at the North Fork site. $R^{2}$ is the correlation coefficient.

Suspended solids $=0.614$ Turbidity +1.49 .

The correlation coefficient is:

$$
\mathrm{R}^{2}=0.73 .
$$

\section{Speedy Point Site}

At the Speedy Point site, 36 of 42 collected water samples were used to determine the relation of suspendedsolids concentration to turbidity in the local space (fig. 10). All turbidity data collected at this site and used for the regression analysis are presented in table 2. Six samples were not used in the regression analysis because of missing or bad turbidity data. The measured suspended-solids concentrations for samples used in this analysis ranged from 4 to $37 \mathrm{mg} / \mathrm{L}$, and corresponding average salinity and temperatures ranged from 0.12 to $22.7 \mathrm{ppt}$ and 20.7 to $31.8^{\circ} \mathrm{C}$, respectively. Even though good correlation was obtained using turbidity data from each of two sensors at this site, average turbidity was used for this analysis. The empirical equation developed for estimating suspended-solids concentrations using turbidity data at this site is expressed as:

$$
\text { Suspended solids }=0.799 \text { Turbidity }+1.76 \text {. }
$$

The correlation coefficient is:

$$
\mathrm{R}^{2}=0.89 .
$$

\section{Qualification of Empirical Equations}

Generally, the accuracy of empirical equations is directly related to how well relevant variables are represented. In this study, equations describing suspended-solids concentrations were calibrated for the North Fork and Speedy Point sites because of site-specific: (1) suspended sediment characteristics (composition and size distribution); and (2) water sampling locations relative to site instrumentation. Thus, each relation is only applicable to the site for which it was developed, as evidenced by comparing the ABS and turbidity relations obtained for each site.

The distribution of parameter data used to develop equations 3 and 4, and relations between residuals and these parameters are shown in figures 11 and 12. For the purpose of these analyses, residuals are calculated by subtracting measured from estimated suspended-solids concentrations using the corresponding empirical equation. The adequacy of these equations appears to be limited by the number and distribution of samples throughout the concentration range, and by changes in the physical characteristics (specifically, the organic to inorganic ratio) of the material in suspension, as shown by apparent trends in figures 11 and 12 . 


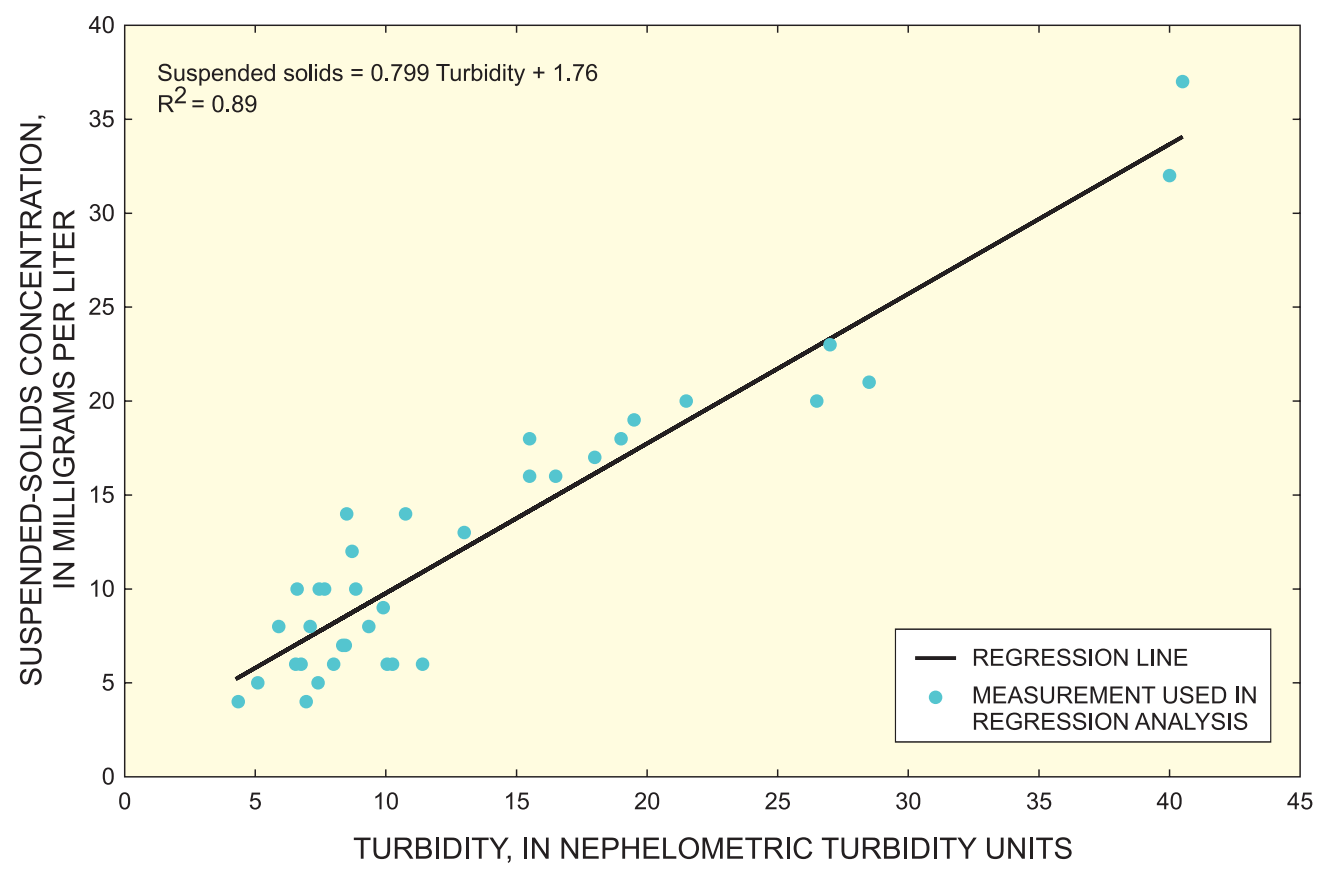

Figure 10. Suspended-solids concentration to turbidity relation at the Speedy Point site. $R^{2}$ is the correlation coefficient.

Trends in the residuals to suspended-solids concentrations graphs indicate that equations 3 and 4 appear to overestimate at the lower range of suspended-solids concentrations and underestimate at the higher range. The accuracy of data calculated using ABS relations as described by equations 3 and 4 may be improved by: (1) increasing the number of water samples to obtain a better distribution of measured suspendedsolids concentrations throughout the expected range; and (2) further studying the effects that changes in the physical composition of suspended-solids, including the organic ratio and varying particle-size distribution, may have on the established relations.

The distribution of parameter data used to develop equations 5 and 6 , and relations between residuals and these parameters are shown in figures 13 and 14 (residuals are calculated as previously described). Again, the adequacy of these equations for describing suspended-solids concentrations may be limited by the number and distribution of samples throughout the expected concentration range. Graphs of the relations between residuals to suspended-solids concentrations in figures 13 and 14 show either weak or nonexistent trends for available data. However, limited measurements were taken throughout the observed concentration range, and increasing the number of water samples to obtain a more complete distribution of measurements may improve the accuracy of the relations.

\section{Sensitivity Analysis}

A sensitivity analysis was performed based on field data collected at the North Fork site on June 2, 1999, and at the Speedy Point site on October 14, 1999. This sensitivity analysis was designed to qualify the response of suspended-solids concentration relations to changes in primary and secondary variables. In this study, field parameters are classified as primary and secondary variables depending on their role in the suspended-solids concentration relations. Turbidity and ABS are considered to be the primary variables, whereas salinity and temperature are considered to be the secondary variables because their role is defined as possible "modifiers" of the suspended-solids concentration relations to ABS and turbidity.

Turbidity relations for the North Fork and Speedy Point sites were developed without use of secondary variables and are shown in figures 9 and 10, respectively. No further tests were necessary because suspended-solids concentration only appears to be related to turbidity; salinity and temperature had no observed effects on the turbidity relations. 

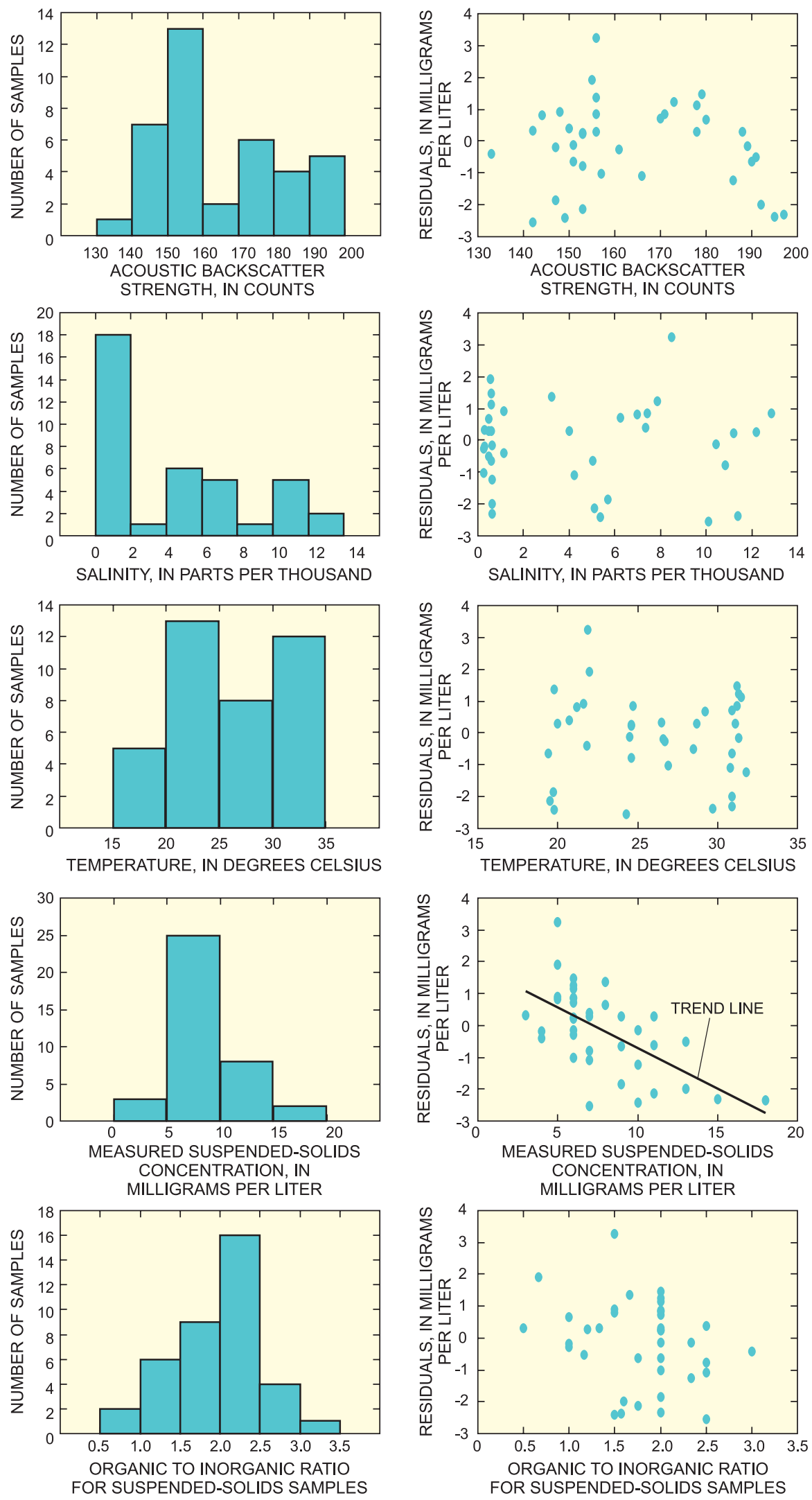

Figure 11. Distribution of parameter data and residuals used in the suspended-solids concentration to acoustic backscatter strength regression analysis at the North Fork site. Circles indicate measurements used in regression analysis. 

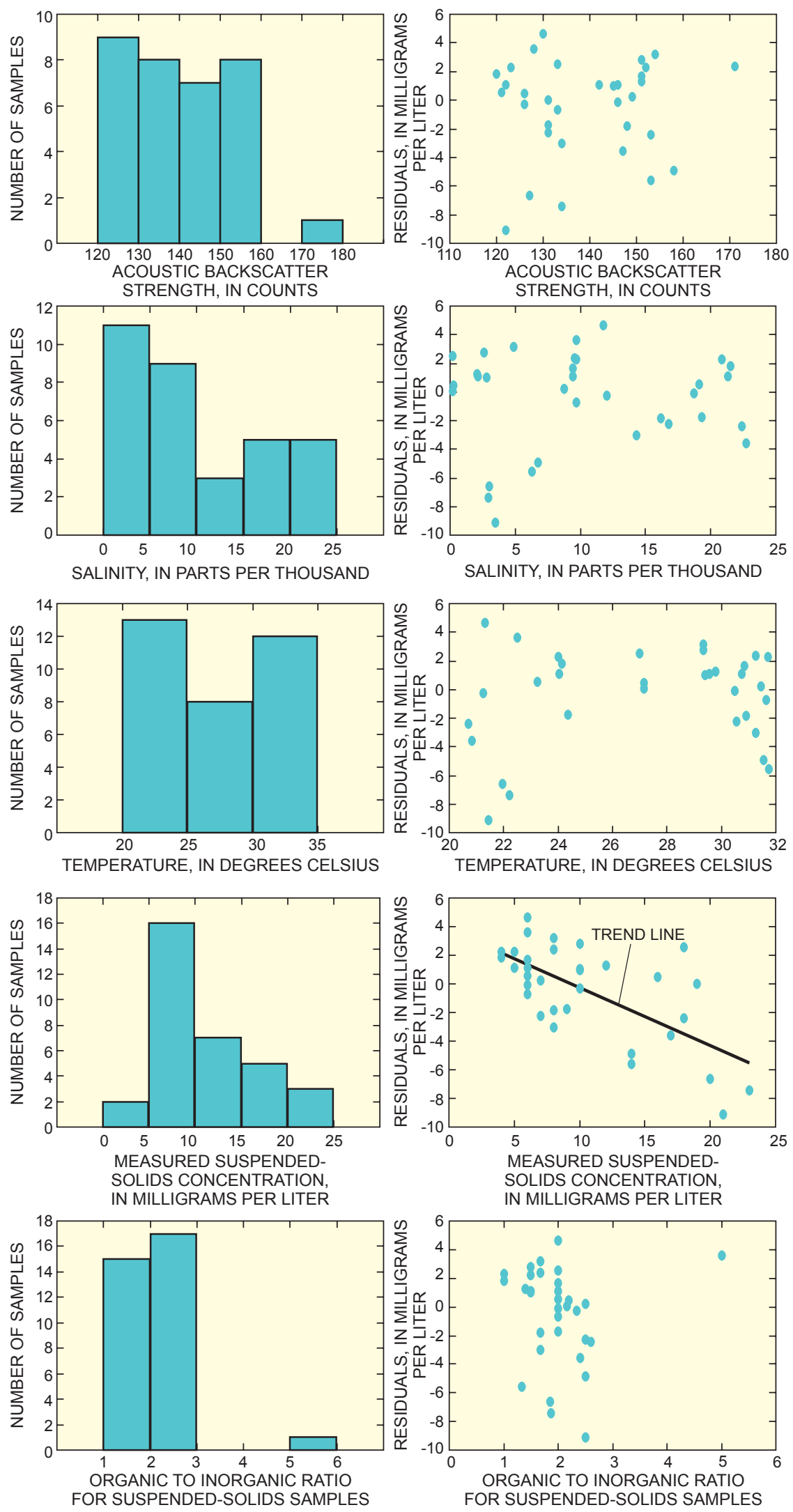

Figure 12. Distribution of parameter data and residuals used in the suspended-solids concentration to acoustic backscatter strength regression analysis at the Speedy Point site. Circles indicate measurements used in regression analysis. 

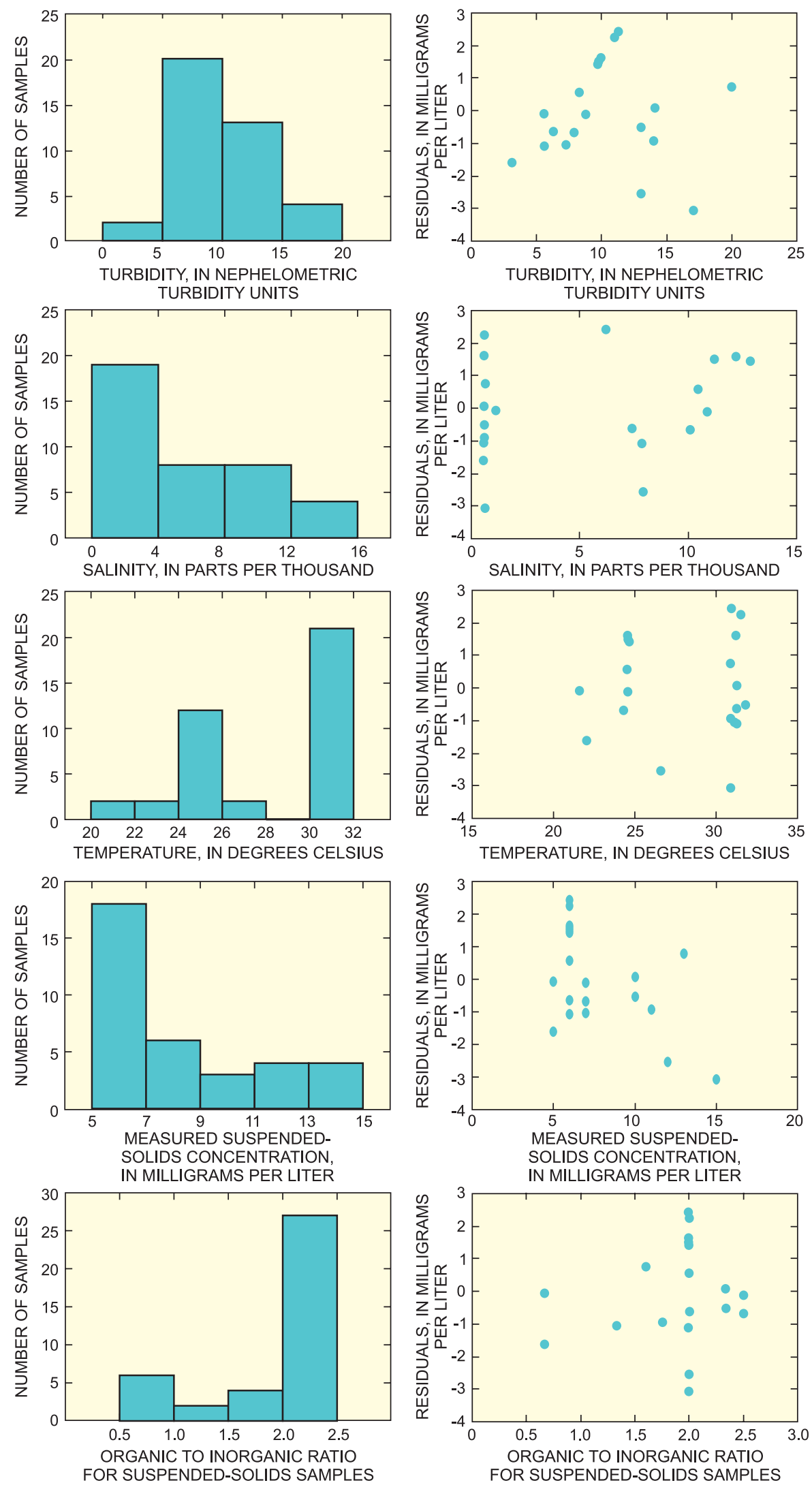

Figure 13. Distribution of parameter data and residuals used in the suspended-solids concentration to turbidity regression analysis at the North Fork site. Circles indicate measurements used in regression analysis. 

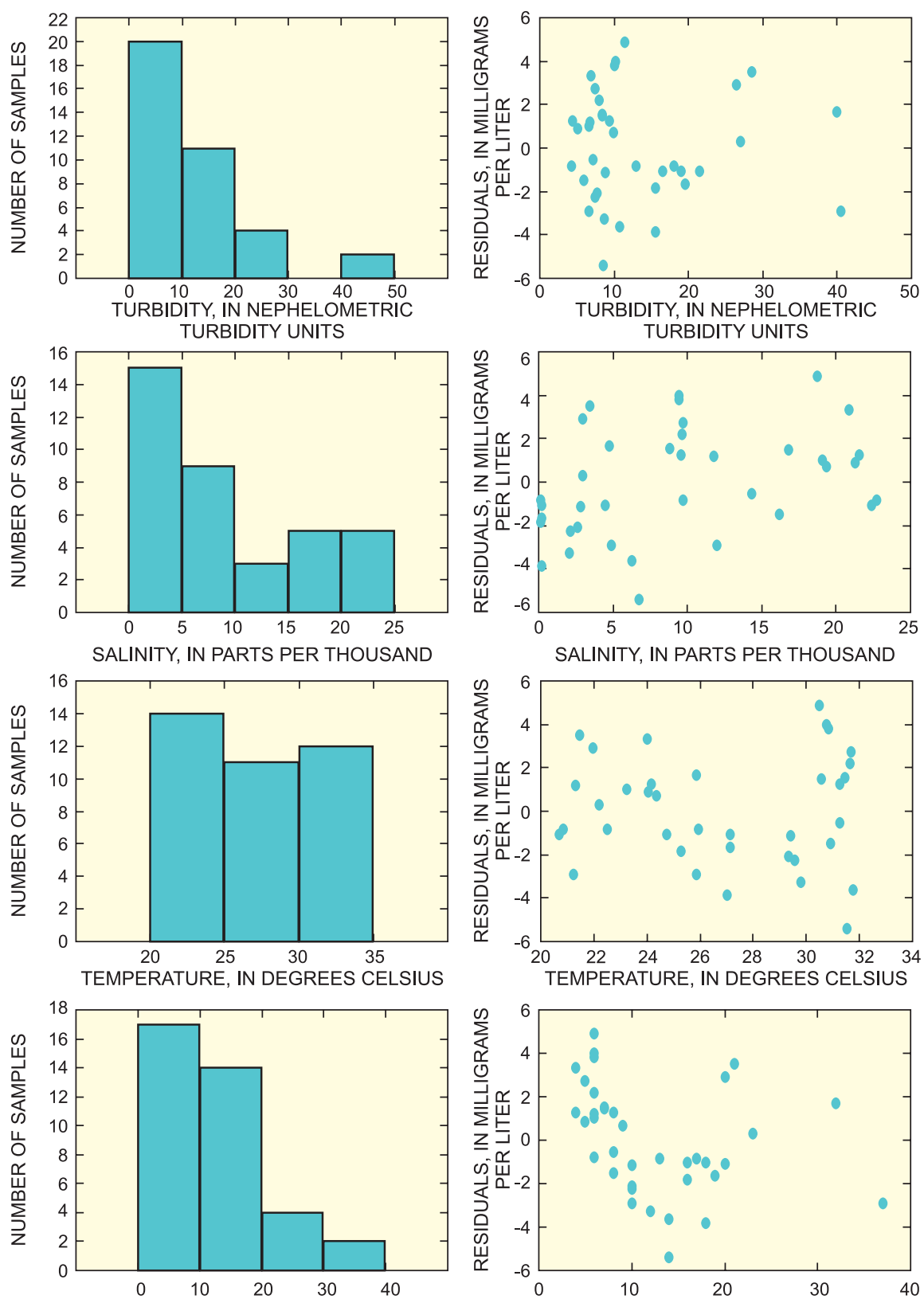

MEASURED SUSPENDED-

SOLIDS CONCENTRATION
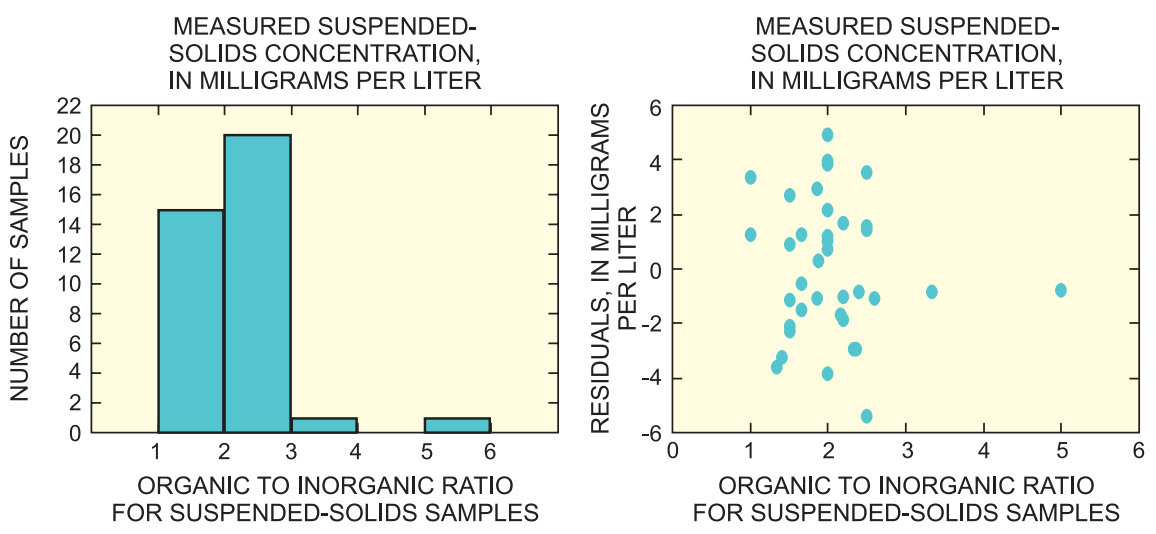

Figure 14. Distribution of parameter data and residuals used in the suspended-solids concentration to turbidity regression analysis at the Speedy Point site. Circles indicate measurements used in regression analysis. 
The ABS relations were developed using ABS as the primary variable, and salinity and temperature as secondary variables. The sensitivity analysis for ABS relations used four tests to determine how the relation responds to each variable. The first test was performed by keeping all variables constant, except for ABS, and computing suspended-solids concentrations for several ABS values within the expected range for each site. As anticipated, suspended-solids concentrations increased in response to increasing ABS values at the North Fork and Speedy Point sites (fig. 15).

Salinity is one of two secondary variables used to account for possible density effects on ABS data because of its role in determining acoustic signal absorption as sound travels across a volume of water. The second test was performed by keeping all variables constant, except for salinity, and computing suspended-solids concentration for several salinity values within the expected ranges at the North Fork and Speedy Point sites (fig. 16). The effect of salinity was found to be minimal; however, it differed between both sites as reflected by the dif-

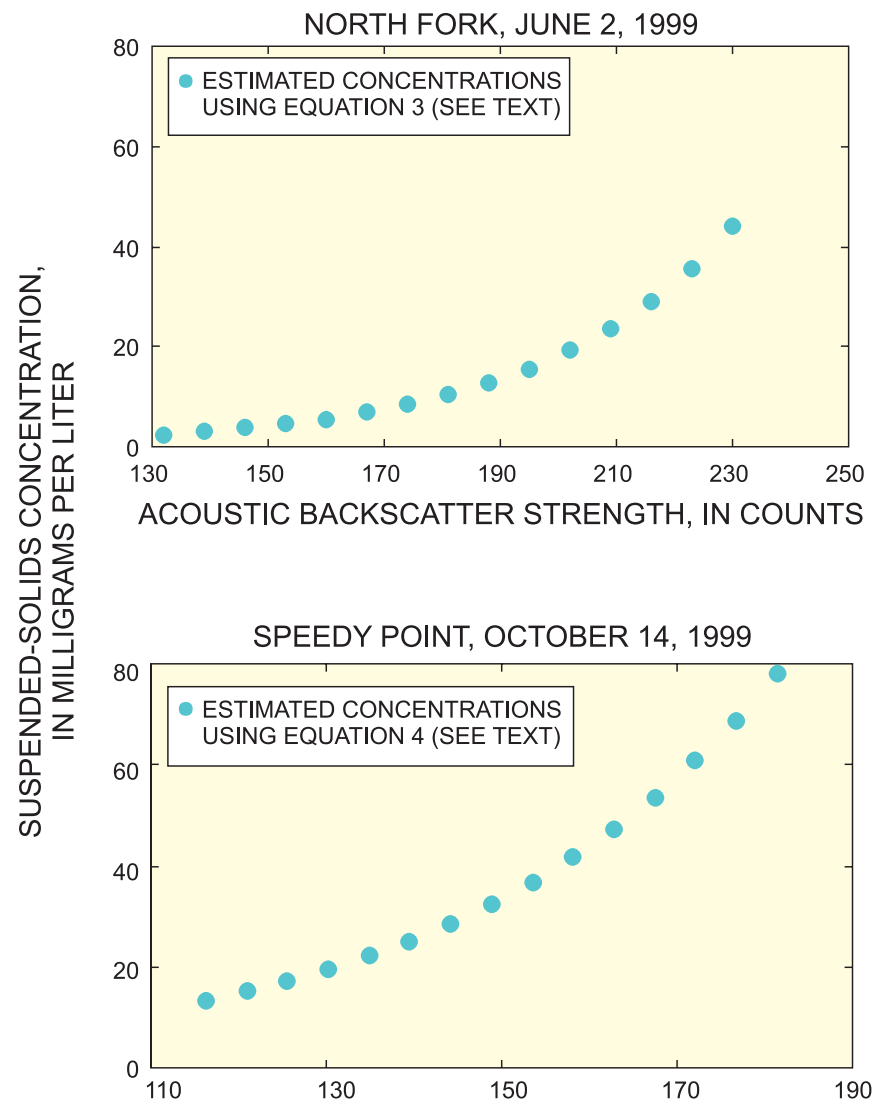

ACOUSTIC BACKSCATTER STRENGTH, IN COUNTS

Figure 15. Acoustic backscatter strength to suspended-solids concentration relation at the North Fork and Speedy Point sites. All variables were kept constant while varying acoustic backscatter strength.

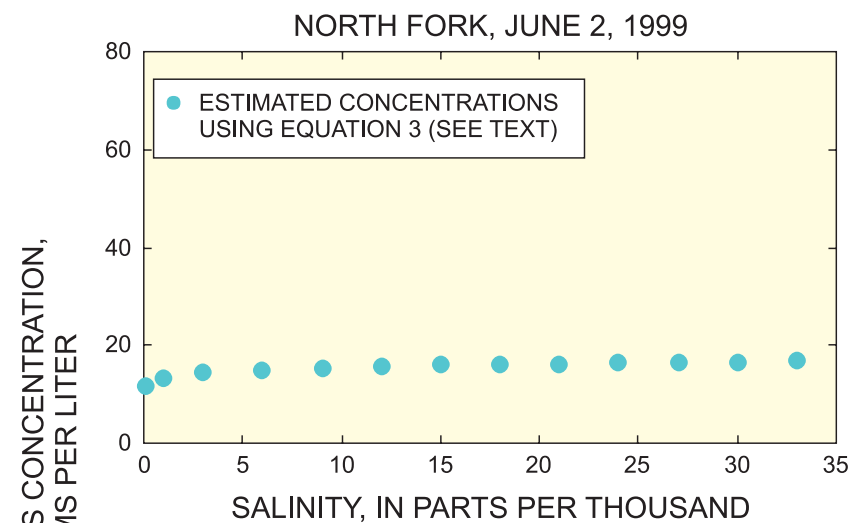

क

员品

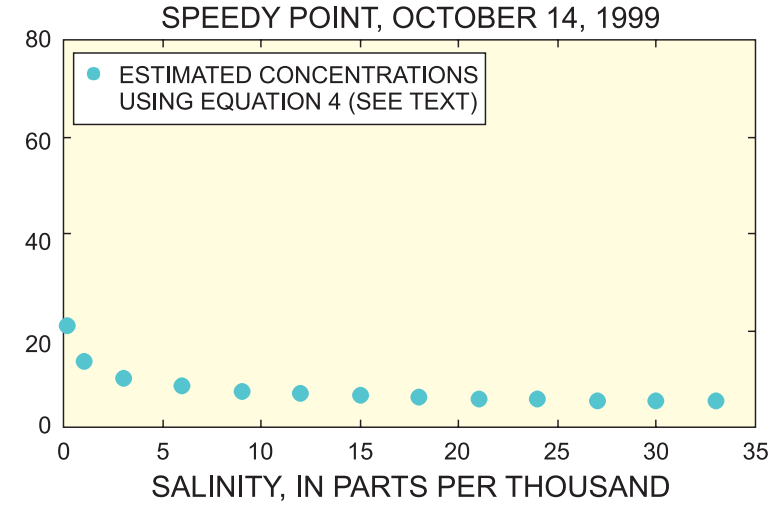

Figure 16. Salinity to suspended-solids concentration relation at the North Fork and Speedy Point sites. All variables were kept constant while varying salinity.

ferent signs for regression coefficients associated with salinity in equations 3 and 4 . This difference may be the result of an insufficient number and distribution of suspended-solids measurements taken throughout the salinity range. Additional suspended-solids measurements throughout the salinity range could help determine if the salinity term is necessary in the suspended-solids equations.

Temperature is the other secondary variable used to account for density effects on ABS data. For the third test, all variables were kept constant, except for temperature. Suspended-solids concentrations were computed for several temperature values within the expected range at the North Fork and Speedy Point sites; the responses are shown in figure 17. Based on results obtained with data from both sites, the effect of temperature in equations 3 and 4 is much greater than that of salinity.

The North Fork site yielded the best available ABS data, and was used to develop an equation that describes suspendedsolids as a function of ABS and water density. Water density was estimated as a function of water temperature and salinity using an equation described by Millero and Poisson (1981), and then used to develop the following equation: 


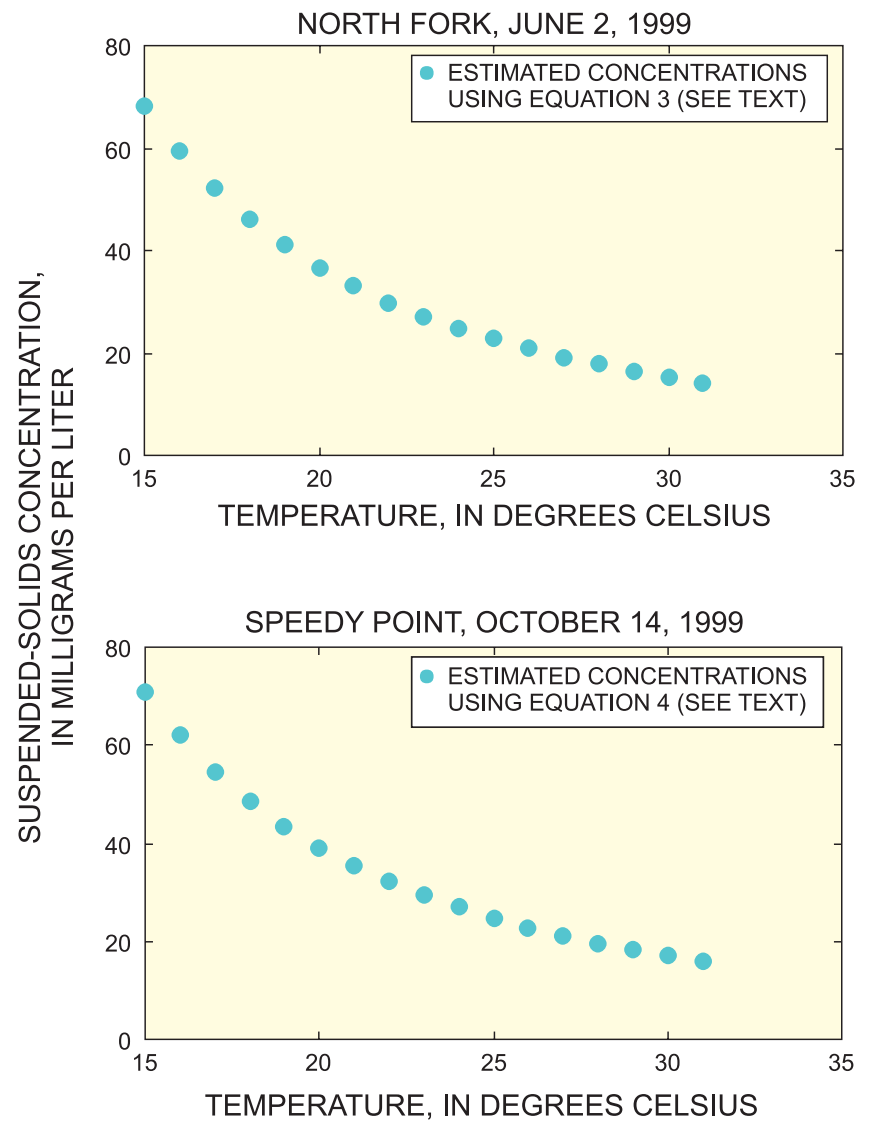

Figure 17. Temperature to suspended-solids concentration relation at the North Fork and Speedy Point sites. All variables were kept constant while varying temperature.

$$
\begin{gathered}
\text { Suspended solids }=10 \text { ABS }[-1.24762+0.4188 \log (\text { density })] \\
-0.54035 .
\end{gathered}
$$

\section{Time-Series Estimates of Mean Suspended-Solids Concentrations}

The potential value of using surrogate data for the calculation of time-series records of mean cross-sectional suspended-solids concentrations lies in the ability to produce data on a continuous basis. This is especially true for periods when data would otherwise not be available, such as during and immediately following significant meteorological events such as tropical storms or hurricanes. Because mean crosssectional concentrations are needed, established local relations must be extrapolated horizontally to represent mean crosssectional concentrations. This is accomplished by collecting simultaneous samples within local and cross-sectional space, and performing correlation analyses to develop relations between the two.

The location where monitoring instruments are placed in a given stream can greatly affect the ability to obtain accurate relations between local (near sensors) and mean concentrations. Vertical and horizontal stratification can affect how well data collected within a small section of a stream can represent the mean cross-sectional conditions. For example, a narrow stream channel, such as at the North Fork site (about $300 \mathrm{ft}$ wide), is more likely to have good correlation between point and cross-sectional data than a wide stream channel, such as at the Speedy Point site (about 1,000 ft wide).

Because the intent of this report is to document the feasibility of using these techniques and not to produce actual records of suspended-sediment loads, the relations described herein are presented for reference only; more data will be necessary to improve and verify these relations. The local (point) to mean cross-sectional suspended-solids concentration relations for data available for the North Fork and Speedy Point sites are shown in figures 19 and 20, respectively.

The correlation coefficient is:

$$
\mathrm{R}^{2}=0.63
$$

The fourth test was used to provide insight about how temperature may affect ABS relations, in addition to the effects related to temperatureinduced changes in water density. North Fork data collected on June 2, 1999, and equations 3 and 7 were used to solve for ABS; all variables were held constant, except for temperature (fig. 18). Temperature values encompassing expected ranges for the North Fork site were used to estimate corresponding ABS values. The results suggest that temperature may have effects on the ABS relations that are unrelated to water density, perhaps by inducing temperaturedependent changes in the absorptive and reflective characteristics of the suspended material within the sampled volume of water.

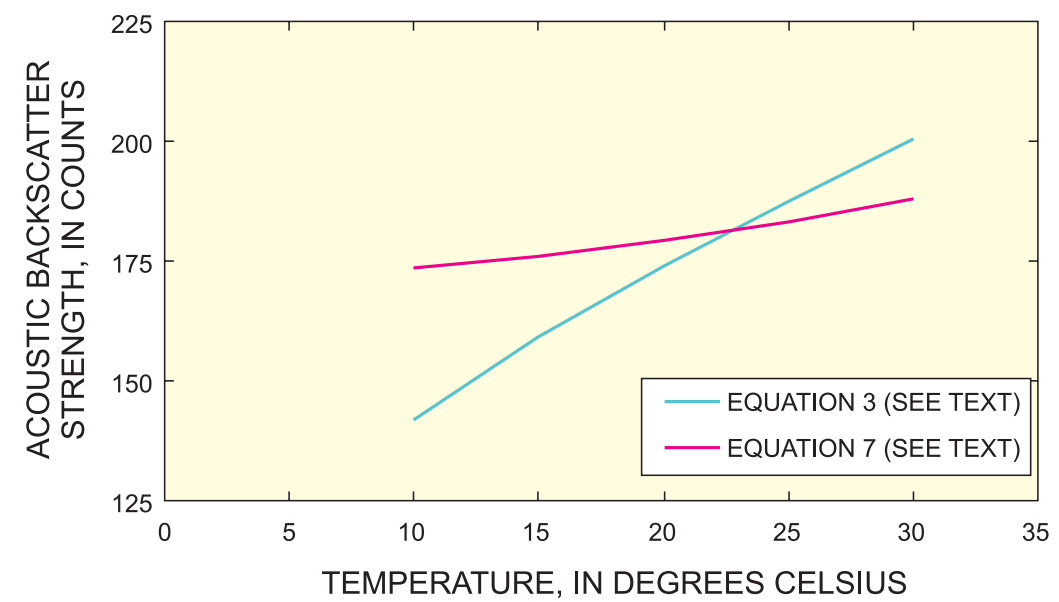

Figure 18. Effect of temperature on acoustic backscatter strength. 


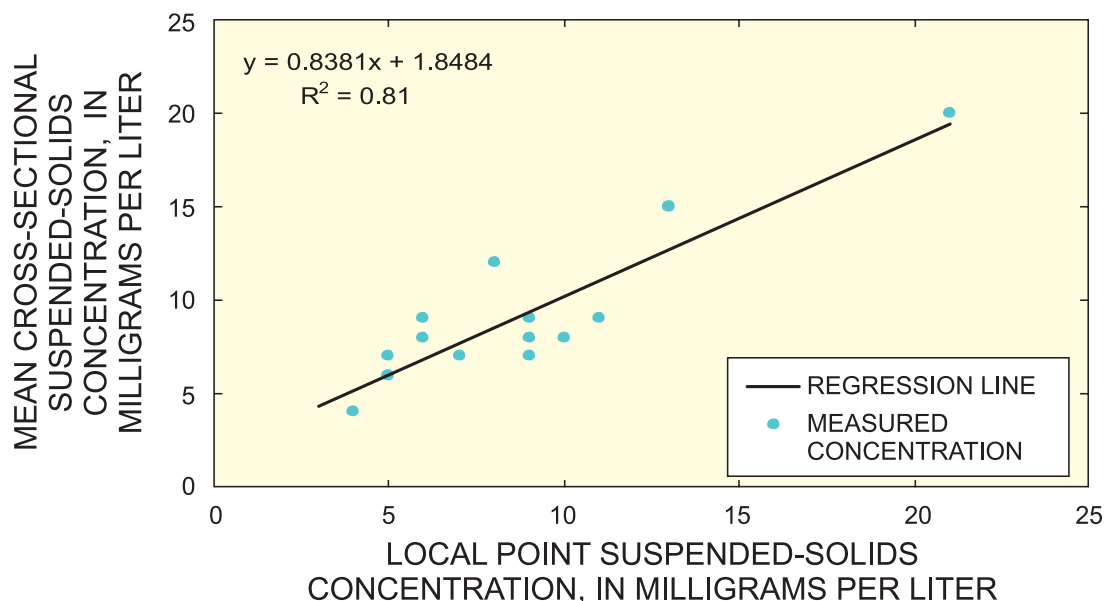

Figure 19. Local point to mean cross-sectional relation for suspended-solids concentration at the North Fork site. $\mathrm{R}^{2}$ is the correlation coefficient.

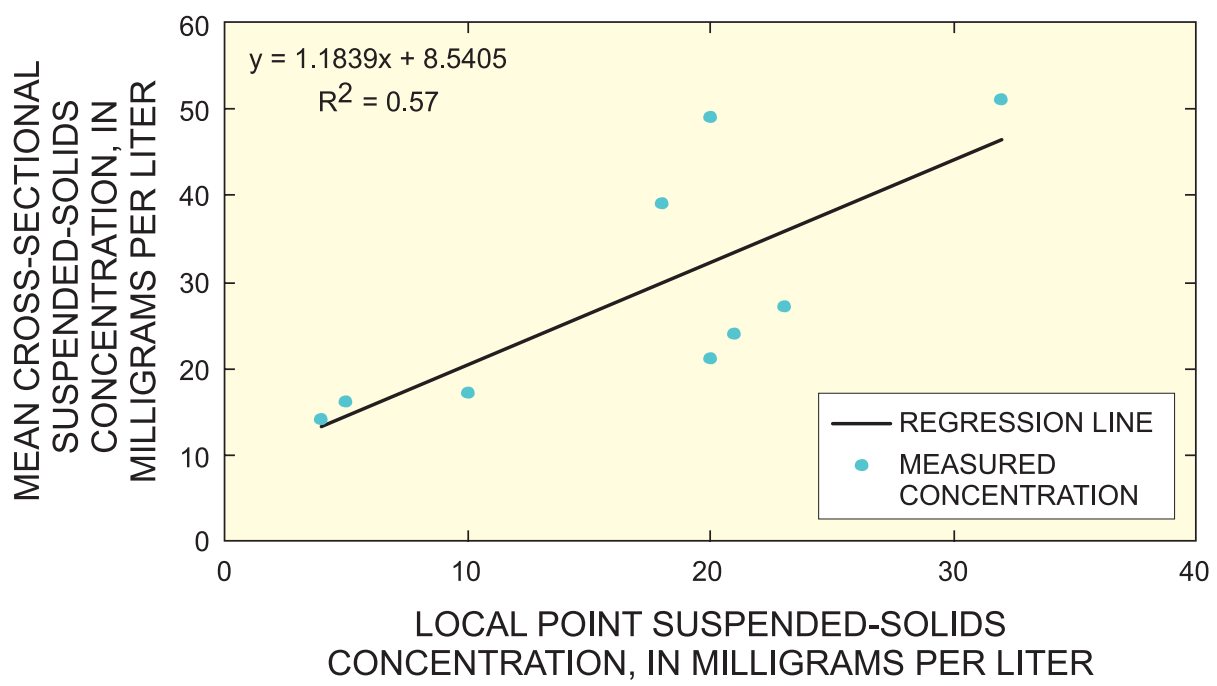

Figure 20. Local point to mean cross-sectional relation for suspended-solids concentration at the Speedy Point site. $R^{2}$ is the correlation coefficient.

The local to mean relation for the North Fork site is:

$$
\begin{aligned}
\text { Suspended solids }_{\text {mean }} & =0.8381 \text { Suspended solids } \\
& +1.8484,
\end{aligned}
$$

and the local to mean relations for the Speedy Point site is:

$$
\begin{aligned}
\text { Suspended solids }_{\text {mean }} & =1.1839 \text { Suspended solids }_{\text {local }} \\
& +8.5405 .
\end{aligned}
$$

The correlation coefficients are $\mathrm{R}^{2}=0.81$ for the North Fork site, and $\mathrm{R}^{2}=0.57$ for the Speedy Point site.

Data used to develop these relations are presented in table 3. Local suspended-solids concentrations were measured by collecting water samples in the local space as previously defined. Cross-sectional concentrations were measured by collecting depth-integrated samples using the EDI method and a DH-59 sampler.

A sample of time-series records of estimated suspendedsolids concentrations was generated using ABS and turbidity data from the North Fork site and equation 8 to transform local estimates to mean cross-sectional concentrations. These estimates are presented with discharge and measured mean suspended-solids concentration in figure 21 . The data from the North Fork site (fig. 21) suggest that time-series records of suspended-solids concentrations estimated using ABS data are less "noisy" than those estimated using turbidity. 
Table 3. Suspended-solids concentrations for the North Fork and Speedy Point sites used to develop local to mean cross-sectional relations.

[units are in milligrams per liter]

\begin{tabular}{|c|c|c|}
\hline Date & $\begin{array}{l}\text { Local point } \\
\text { samples }\end{array}$ & $\begin{array}{l}\text { Cross -sectional } \\
\text { samples }\end{array}$ \\
\hline \multicolumn{3}{|c|}{ North Fork Site } \\
\hline $10-18-99$ & 13 & 15 \\
\hline $10-18-99$ & 8 & 12 \\
\hline $11-19-99$ & 5 & 6 \\
\hline $11-19-99$ & 5 & 6 \\
\hline $12-05-99$ & 9 & 9 \\
\hline $12-05-99$ & 11 & 9 \\
\hline $12-05-99$ & 9 & 7 \\
\hline $12-05-99$ & 10 & 8 \\
\hline $12-05-99$ & 9 & 8 \\
\hline $12-14-99$ & 4 & 4 \\
\hline $01-06-00$ & 7 & 7 \\
\hline $02-24-00$ & 5 & 7 \\
\hline $03-24-00$ & 6 & 8 \\
\hline $03-24-00$ & 6 & 9 \\
\hline $03-24-00$ & 7 & ${ }^{1} 19$ \\
\hline $05-16-00$ & 21 & 20 \\
\hline \multicolumn{3}{|c|}{ Speedy Point Site } \\
\hline $11-19-99$ & 21 & 24 \\
\hline $11-19-99$ & 20 & 21 \\
\hline $11-19-99$ & 23 & 27 \\
\hline $01-06-00$ & 10 & 17 \\
\hline $02-24-00$ & 18 & 39 \\
\hline $03-24-00$ & 4 & 14 \\
\hline $03-24-00$ & 5 & 16 \\
\hline $04-28-00$ & 32 & 51 \\
\hline $05-04-00$ & 20 & 49 \\
\hline
\end{tabular}

${ }^{1}$ Biased sample due to bottom sediment resuspension during sampling; data were not used in the analysis and are shown here solely for documentation.

\section{Summary and Conclusions}

Acoustic and optic methods were applied in a study to estimate suspended-solids concentrations in the St. Lucie River Estuary, southeastern Florida. Instrument installation and field data collection and analysis were performed at the North Fork site in southern St. Lucie County and at the Speedy Point site in northern Martin County. These sites provide varying flow, salinity, water-quality, and channel cross-sectional characteristics. A third monitoring site, Steele Point, was not used in the analysis because bridge construction resulted in several instrument relocations that prevented a sufficient number of measurements from being taken at any of the locations used.

Acoustic Doppler velocity meter instruments were installed to measure an index of the mean water velocity at surface-water monitoring sites and to record information about the strength of the return signal-acoustic backscatter strength (ABS)—received by the sensor, a parameter affected primarily by the amount of material in suspension. Additionally, optic sensors were installed to measure the turbidity of the water at these sites. Water samples were collected using point and depth-integrated samplers to measure local and mean crosssectional suspended-solids concentrations, respectively.

Regression analyses were used to determine the relations of suspended-solids concentration to ABS and suspendedsolids concentration to turbidity at the North Fork and Speedy Point sites. Usable measurements of suspended-solids concentrations ranged from 3 to $18 \mathrm{mg} / \mathrm{L}$ at the North Fork site and from 4 to $37 \mathrm{mg} / \mathrm{L}$ at the Speedy Point site. The organic content of suspended solids measurements made at both sites ranged from 50 to 83 percent. The suspended-solids concentrations and organic content varied depending on the monitoring site location and flow conditions at the time of

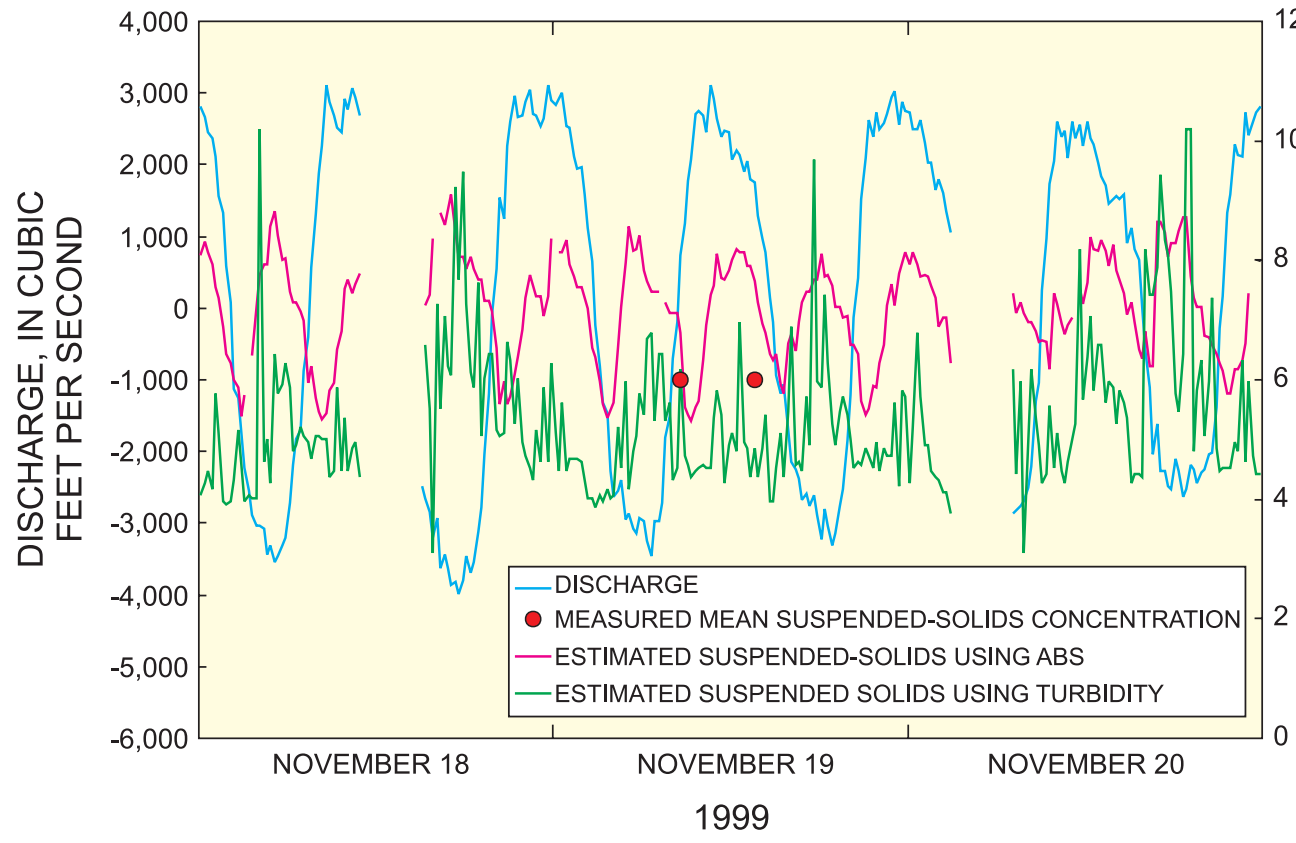

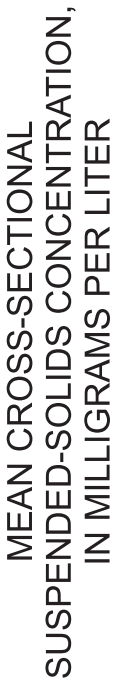

Figure 21. Discharge and mean cross-sectional suspended-solids concentrations at the North Fork site. ABS is acoustic backscatter strength. 
sampling. For samples used in the regression analyses, salinity ranged from 0.12 to 22.7 parts per thousand, and temperature ranged from 19.4 to $31.8^{\circ} \mathrm{C}$.

Salinity and temperature data were collected as waterquality characteristics and to account for water-density effects on ABS data. These data were used as secondary variables in regression analyses to develop the estimation equations. Salinity and temperature data used for the ABS relation ranged from 0.2 to $12.9 \mathrm{ppt}$ and 19.4 to $31.8{ }^{\circ} \mathrm{C}$, respectively, at the North Fork site and ranged from 0.2 to $22.7 \mathrm{ppt}$ and 20.7 to $31.8^{\circ} \mathrm{C}$, respectively, at the Speedy Point site.

All relations described herein are site specific and are only useful for estimating suspended-solids concentrations for locations where data were collected. Because of an insufficient number of equal discharge increment samples, all suspendedsolids concentration relations developed as part of this study are relations in the local space (near the sensors) and do not represent mean suspended-solids concentrations of the entire cross section. The suspended-solids concentration to ABS relations for the North Fork and Speedy Point sites resulted in correlation coefficients of 0.78 and 0.63 , respectively. The suspended-solids concentration to turbidity relation at the North Fork and Speedy Point sites resulted in correlation coefficients of 0.73 and 0.89 , respectively.

The adequacy of these empirical equations appears to be limited by the number and distribution of suspended-solids samples taken throughout the expected concentration range at both sites. Additionally, the ABS relations for both sites seem to overestimate at the low end and underestimate at the high end of the concentration range. The physical composition (organic to inorganic ratio) of the suspended material in samples taken also seems to partly determine how well the ABS relations represent suspended-solids concentrations, as shown by the analysis of North Fork data. Combining ABS and turbidity data into one equation did not improve the accuracy of results, and therefore, this approach was not considered in the final analysis.

Based on the sensitivity analysis, temperature had a greater effect than salinity on estimated suspended-solids concentrations. In addition to affecting ABS data by changing water density, temperature also appeared to affect ABS data by changing the absorptive and reflective characteristics of the suspended material. Salinity and temperature had no observed effects on the turbidity relation at the North Fork and Speedy Point sites.
In a mathematical comparison, estimates of suspendedsolids concentrations using ABS data were "less" erratic than estimates using turbidity data. The overall results of the study suggest that this technique has the potential to adequately describe time-series estimates of suspended-solids concentrations in the St. Lucie River Estuary. However, the accuracy with which the empirical equations describe these estimates may be improved by: (1) increasing the number of water samples to obtain better distributions of measured suspended-solids concentrations and local to mean cross-sectional relations; and (2) further studying the effects that changes in the physical composition of suspended-solids may have on ABS relations.

\section{References Cited}

Edwards, T.K., and Glysson, G.D., 1988, Field methods for measurement of fluvial sediment: U.S. Geological Survey Open-File Report 86-531, 118 p.

Gray, J.R., Glysson, G.D., Turcios, L.M., and Schwartz, G.E., 2000, Comparability of suspended-sediment concentration and total suspended solids data: U.S. Geological Survey Water-Resources Investigations Report 00-4191, 20 p.

Millero, F.J., and Poisson, Alain, 1981, International one atmosphere equation of state for seawater: Deep-Sea Research, v. 28A, p. 625-629.

SonTek, 1997, SonTek Argonaut-Acoustic Doppler current meter: San Diego, Calif., Technical Documentation, 127 p.

South Florida Water Management District, 1999, Focus on the St. Lucie River: West Palm Beach, November, unnumbered.

Steward, Joel, Virnstein, Robert, Haunert, Dan, and Lund, Frank, 1993, Draft Surface Water Improvement and Management (SWIM) Plan for the Indian River Lagoon: West Palm Beach, South Florida Water Management District.

U.S. Interagency Committee on Water Resources, Subcommittee on Sedimentation, 1965, Instructions for sampling with depth-integrating sediment samples US D-49 and DH-59: Report O, $175 \mathrm{p}$.

YSI Incorporated, 1998, Environmental monitoring systemsOperations manual: Yellow Springs, Ohio, YSI Publication, $255 \mathrm{p}$. 